\title{
DIATOMS, PROTEIN AND CARBOHYDRATE SEDIMENT CONTENT AS PROXIES FOR COASTAL EUTROPHICATION IN MONTEVIDEO, RIO DE LA PLATA ESTUARY, URUGUAY
}

\author{
Felipe Garcia-Rodriguez ${ }^{I^{*}}$, Laura del Puerto ${ }^{2}$, Natalia Venturini ${ }^{1}$, Ana Laura Pital, \\ Ernesto Brugnoli ${ }^{l}$,Leticia Burone ${ }^{l}$ and Pablo Muniz ${ }^{l}$
}

${ }^{1}$ Universidad de la República, Facultad de Ciencias - Seccion Oceanologia (Iguá 4225, Montrevideo 11400, Uruguay)

\author{
${ }^{2}$ Ministerio de Educación y Cultura, Uruguay /Centro Universitario Regional Este (CURE), Sede Rocha, \\ Universidad de la República \\ (Iguá 4225, Montevideo 11400, Uruguay)
}

*Corresponding author: felipe.garciarodriguez@gmail.com

\begin{abstract}
A study on sediment surface diatom composition in relation to both protein/carbohydrate content and salinity was carried out in Montevideo Bay and the adjacent coastal zone. Samples were seasonally taken during one year along a human impact gradient, and the trophic conditions were assessed from the biochemical composition of the surface sediment organic matter. The co-occurrence of the marine-brackish (Actinocyclus curvatulus, Actinocyclus gallicus, Coscinodiscus excentricus, Coscinodiscus radiatus, Hyalodiscus subtilis, Paralia sulcata) and freshwater diatom flora (Aulacoseira granulata, Aulacoseira italica, Aulacoseira muzzanensis, Actinocyclus normanii, Amphora copulata, Cyclotella meneghiniana, Nitzschia linearis), suggests myxohaline estuarine conditions in the study area. The sampling stations located within the bay, close to several contamination sources, exhibited hypertrophic conditions as indicated by the highest levels of protein content, but also by the high relative abundances of Actinocyclus normanii and Cyclotella meneghiniana, as both diatom species are very well established cosmopolitan proxies of aquatic degradation. The levels of both protein and carbohydrate content, but also photosynthetic pigments, recorded in the adjacent coastal zone suggest meso-eutrophic conditions as contamination levels from the inner bay might become diluted off shore. Multivariate diatom species-environmental data relationships, indicate that the trophic gradient is hierarchically more important than salinity in explaining the diatom distribution. The present data imply an improvement in our ability of assessing organic contamination in the study area, since both biological and biopolymer variables were introduced for the first time as a tool for assessing the benthic health/degradation in one of the most populated regions of the Río de la Plata.
\end{abstract}

\section{RESUMO}

Foi realizado um estudo da salinidade e da composição das diatomáceas presentes no sedimento superficial em relação ao conteúdo de proteínas/carboidratos na Baía de Montevidéu e região costeira adjacente. Foram obtidas amostras sazonalmente durante um ano ao longo de um gradiente de impacto ambiental humano, e as condições tróficas foram determinadas através da análise da composição bioquímica da matéria orgânica do sedimento superficial. A coocorrência de espécies de diatomáceas marinhas-salobras, (Actinocyclus curvatulus, Actinocyclus gallicus, Coscinodiscus excentricus, Coscinodiscus radiatus, Hyalodiscus subtilis, Paralia sulcata) e diatomáceas indicadoras de águas doces (Aulacoseira granulata, Aulacoseira italica, Aulacoseira muzzanensis, Actinocyclus normanii, Amphora copulata, Cyclotella meneghiniana, Nitzschia linearis) sugerem condições mixohalinas estuarinas na área de estudo. As estações amostradas dentro da baía, próximas às fontes contaminadoras, apresentam condições hipertróficas apontadas pelos maiores valores de proteínas e pela alta abundância relativa de Actinocyclus normanii e Cyclotella meneghiniana, sendo que ambas espécies são consideradas cosmopolitas e indicadoras de degradação aquática. As concentrações de proteínas e carboidratos, bem como os pigmentos fotossintéticos registrados na região costeira adjacente sugerem condições meso-eutróficas e uma diluição dos níveis de contaminação do interior da baía rumo à região externa. A análise multivariada entre espécies de diatomáceas e parâmetros ambientais indica que o gradiente trófico possui hierarquicamente maior peso que a salinidade na explicação da distribuição das diatomáceas. Os resultados obtidos demonstram um aperfeiçoamento na habilidade de determinar a contaminação orgânica dentro da área de estudo, já que pela primeira vez tanto as variáveis orgânicas quanto os biopolímeros foram introduzidos como ferramenta para a determinação da relação degradação/saúde de uma das mais populosas regiões do Río de la Plata.

Descriptors: Diatoms, Carbohydrates, Proteins, Estuaries, Coastal eutrophication, Uruguay. Descritores: Diatomeas, Carbohidratos, Proteínas, Estuarios, Eutrofización costera, Uruguay. 


\section{INTRODUCTION}

During the last five years, the Río de la Plata estuary has become increasingly important as an international biodiversity reserve of the biosphere (FREPLATA, 2004). The estuary lies within the second largest hydrographic basin in South America, and it is strongly influenced by the freshwater input of two large rivers (i.e., Uruguay and Paraná) and the intrusion of marine water from the Atlantic Ocean. In addition, the influence of both warm and cold water masses from the Brazil and the Malvinas currents, leads to great environmental heterogeneity (ACHA et al., 2008). Such natural heterogeneity, combined with profound human impact (i.e., due to overfishing, diverse sources of chemical and biological contamination, urban development, population increase and navigation) (FREPLATA, 2004; CARPCTMFM, 1999), implies that the development and testing of environmental impact assessment tools are very important for the management of the system. This is imperative, especially in populated areas such as Buenos Aires and Montevideo, the two most important cities and harbor areas of the Río de la Plata.

Montevideo city contains a highly active harbor that received 317,000 containers in 2008, which represents approximately 1.5 million tons of goods. In addition to this intense harbor activity, an oil refinery, a large number of leather/food-industry facilities and a thermoelectric station, are located in the catchment area of Montevideo Bay. Thus, there are several sources of potential environmental degradation to this system. A number of contamination studies have already been carried out in this area, the most comprehensive of which (MOYANO et al., 1993; DANULAT et al. 2002; MUNIZ et al., 2002; 2004a, b; VENTURINI et al., 2004; BURONE et al., 2006; BRUGNOLI et al., 2007) have assessed the environmental degradation of Montevideo Bay and the adjacent coastal zone. These papers have focused on the influence of heavy metals and hydrocarbons on benthic communities in order to demonstrate the negative impact of the industrial operations concerned on the ecosystem's health. It has been concluded that the benthic system of Montevideo Bay faces extremely harmful conditions, because of the combined action of all the pollutants (e.g., BURONE et al., 2006), though with a relative improvement of environmental conditions off the bay (VENTURINI et al., 2004). However, in addition to the pollutants, there is also a severe eutrophication problem in the bay (NAGY et al., 2002).

The eutrophication of coastal waters can be related to the urbanization of coastal drainage basins, agricultural activities and also human and industrial discharges. Most eutrophication assessments are performed by combining water column variables such as total $\mathrm{N}$ and $\mathrm{P}$ concentrations, oxygen saturation, turbidity, algal biomass and primary production (VOLLENWEIDER et al., 1998). This is also the case for the Río de la Plata (e.g. NAGY et al., 2002; CALLIARI et al., 2009). However, more recent approaches take into account the benthic compartment and/or the coupling of the pelagic/benthic domains, because the sediment constitutes a complete record of information on the water column processes. In addition, eutrophication should not only be understood as the increment of inorganic nutrients or productivity in the system, but also as the accumulation of organic carbon in bottom sediments (CLOERN, 2001). Because of the conservative nature of organic carbon, more recent techniques take into consideration the biochemical composition of sedimentary organic matter to assess eutrophication trends in coastal marine environments. In particular, sediment protein and carbohydrate concentrations appear to be good descriptors of the trophic state of the benthic system, as demonstrated by Dell' Anno et al. (2002).

As a result of excessive nutrient loads and increased organic matter production, the sedimentation rate of organic matter may exceed that of its degradation and bottom water oxygen may be exhausted, thus influencing benthic environmental conditions and biotic communities. Benthic diatoms are sensitive to many environmental variables, including light, temperature, current velocity, salinity, $\mathrm{pH}$, oxygen, nutrients, organic carbon and organic nitrogen (VAN DAM et al., 1994; WILSON et al., 1994; KELLY, 1998; WITKOWSKI et al., 2000; PRYGIEL; COSTE 2000; WELKER et al., 2002; GARCÍA-RODRÍGUEZ et al., 2007a). They are, therefore, very well established as organisms for the assessment of environmental degradation.

This study aims to assess the trophic state of Montevideo Bay and the adjacent coastal zone, using biochemical descriptors in surface sediments, combined with microalgae biomass and community data, as a tool to identify zones with different trophic degrees, and relate them to both contamination sources and natural variability.

\section{The Study Area}

The Montevideo coastal zone lies between $34^{\circ} 50^{\prime}-34^{\circ} 56^{\prime} \mathrm{S}$ and $56^{\circ} 05^{\prime}-56^{\circ} 25^{\prime} \mathrm{W}$ (Fig. 1). It is located on the central part of the coast of the Río de la Plata which lies within the second largest basin in South America. The Río de la Plata is a tidal river with a coastal plain and a semi-enclosed shelf sea at the mouth. Salinity, halocline depth and vertical mixing vary with astronomic tidal oscillation on an hourly basis, while axial winds influence water height and salinity on a daily basis (NAGY et al., 1997). The 
mean annual river flow that determines from monthly to interannual variations is $25,000 \mathrm{~m} 3 \mathrm{~s}-1$.

The system is characterized by large amounts of suspended particulate matter (SPM), a high nitrogen : phosphorous ratio $(\mathrm{N}: \mathrm{P}>25)$, moderate chlorophyll a, and the occurrence of cyanobacteria blooms (NAGY et al., 2002). Seaward of the salinity front, where both SPM and nutrient concentrations are lower and chlorophyll a values greater, the net ecosystem metabolism is positive. Permanent stratification controls nutrient, organic matter and oxygen dynamics, leading to biological stress and hypoxia below the halocline. Periodic nuisance and toxic blooms occur at high salinities along the Uruguayan coast (NAGY et al., 2002). The assessment of the regional and overall ranking of eutrophic conditions determines that the system is moderately eutrophic (NAGY et al., 2002). However, increased freshwater and nutrient loads, and the low potential for the dilution and flushing of nutrients, suggest that the Rio de la Plata, is prone to a worsening of eutrophication conditions such as oxygen stress and harmful blooms (NAGY et al., 2002).

Montevideo Bay has an approximate area of $10 \mathrm{~km} 2$. It holds a petroleum refinery, the BatlleThermoelectric Facility and the Montevideo Harbor. Three streams flow into it, the Miguelete Stream, the Pantanoso Stream and the Seco Stream, this latter through an artificial pipe-line. These streams carry waste from many different industries, povertystricken settlements and a large number of sewage pipes. Modern sediments are mainly constituted of silt and clay fractions (AYUP, 1986). The predominant winds, from the NE and W-SW, are very important in determining the water circulation, mainly clockwise, at shallow depths (MORESCO; DOL, 1996).

According to Muniz et al. (2002), the inner part of Montevideo Bay has higher sediment heterogeneity, higher organic load and lower oxygen content in surface sediments than do the outermost part of the bay and the adjacent coastal zone (i.e. Pta. Carretas and Pta. Yeguas). This inner part of Montevideo Bay is grossly polluted by $\mathrm{Cr}, \mathrm{Pb}$ and petroleum hydrocarbons, while the other zones show moderate pollution (VENTURINI et al., 2004). Danulat et al. (2002) have defined the Montevideo Harbor as a hyper-eutrophic system, which receives considerable nutrient and organic loads. Burone et al. (2006) recorded $\mathrm{Cr}$ values of $657.1+76.3 \mathrm{mg} \mathrm{kg}-1$ and $\mathrm{Pb}$ values of $369.6+54.23 \mathrm{mg} \mathrm{kg}^{-1}$ within Montevideo Bay, and $\mathrm{Cr}$ values of $38.1+2.12 \mathrm{mg}$ $\mathrm{kg}^{-1}$ and $\mathrm{Pb}$ values of $54.9+4.91 \mathrm{mg} \mathrm{kg}^{-1}$ in the adjacent coastal zone.

One of the most important environmental problems in that part of the study area where many industrial facilities are located, is the lack of a sanitation system (Fig. 1). Although a sanitation system is being constructed, the finalization of this project is planned for 2020 , when $100 \%$ of the city will be covered by the sanitation system. Thus, the control and management of such industries is a priority issue. Further information on the study area has been published elsewhere (DANULAT et al., 2002; MUNIZ at al., 2002, 2004a, b; BURONE et al., 2006).

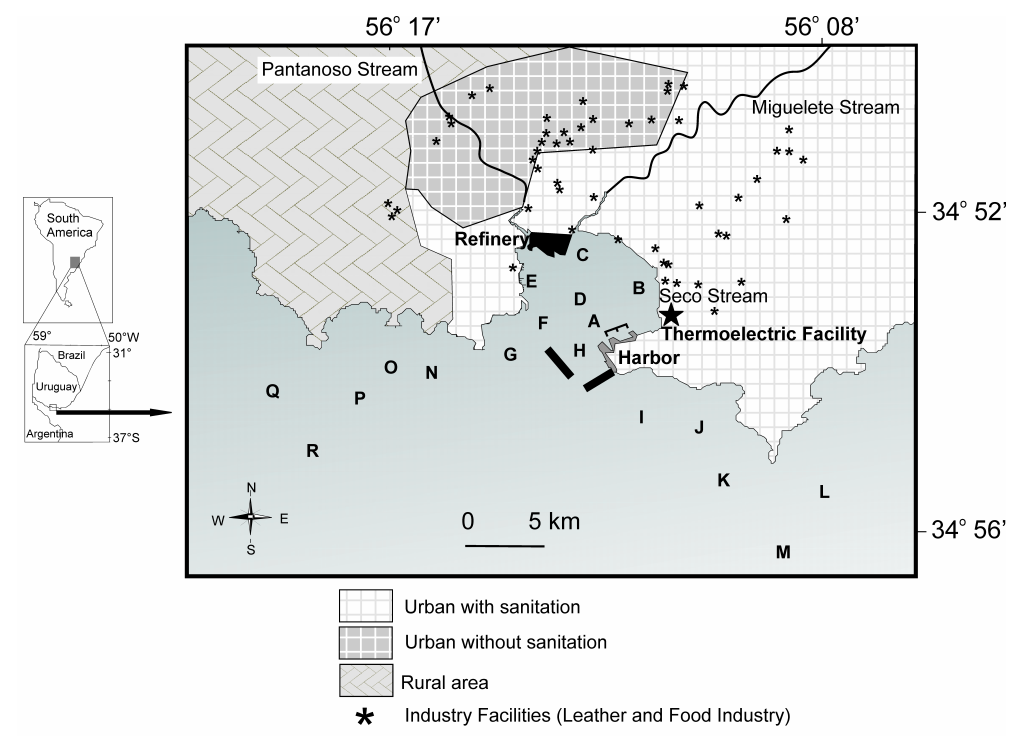

Fig. 1. The study area. Capital letters indicate the position of the sampling stations Most important industry facilities are indicated with asterisks in the figure. 


\section{Materials ANd Methods}

\section{Field and Laboratory Methods}

Surface sediment samples were seasonally (winter, spring, summer and autumn) collected at 18 stations, from July 2007 to May 2008 (Fig. 1). At each station two replicates of van Veen sediment grab were taken $\left(0.05 \mathrm{~m}^{2}\right)$. The grab was always opened gently to avoid sediment surface disturbance. On board, surface subsamples were taken for the analysis of diatoms, chlorophyll- $a$, phaeopigments, total organic matter, organic biopolymers and sediment type. They were immediately frozen at $-20^{\circ} \mathrm{C}$ in aluminum containers until analysis. Conductivity, temperature, $\mathrm{pH}$ and dissolved oxygen in bottom water (i.e. $10 \mathrm{~cm}$ above the sediment surface) were measured with an $\mathrm{YSI}^{\circledR}$ multi-parameter device, and depth was measured using a Hummingbird ${ }^{\circledR}$ echo-sounder. The bottom oxygen saturation percentages were calculated according to the equation of Weiss (1970).

Samples for diatom counting and identification were treated with $2 \mathrm{~N} \quad \mathrm{Na}_{4} \mathrm{P}_{2} \mathrm{O}_{7}$ to deflocculate the sediment and remove clay. Then, 15 $\mathrm{ml}$ of $35 \% \mathrm{HCl}$ were added and allowed to stand for 24 hours to eliminate carbonates, and rinsed five times with distilled water. Next, $10 \mathrm{ml}$ of $30 \% \mathrm{H}_{2} \mathrm{O}_{2}$ were added to eliminate organic matter, and then the samples were boiled for four hours and rinsed five times with distilled water. Permanent slides were mounted in Naphrax ${ }^{\circledR}$ for counting and identification. A minimum of 300 valves was counted at $1000 x$ magnification in each sample. Species were identified according to Frenguelli (1941, 1945), Müller-Melchers (1953), Metzeltin and García-Rodríguez (2003), Metzeltin et al. (2005).

One sub-sample (ca. $100 \mathrm{~g}$ ) was submitted to the standard dry-sieve and pipette method (SUGUIO, 1973) and parameters described by Folk and Ward (1957) were calculated for sedimentological data. Three sub-samples were used to determine photosynthetic pigment content of surface sediments according to Lorenzen (1967). Sediment protein and carbohydrate content were analyzed from the third sub-sample colorimetrically. Proteins (PRT) were extracted in $0.5 \mathrm{NaOH}$ during 4 hours and analyzed following the method of Lowry et al. (1951) modified by Hartree (1972) with the compensation for phenol interference proposed by Rice (1982) and concentrations expressed as bovine serum albumin (BSA) equivalents. Carbohydrates (CHO) were analyzed by the method of Dubois et al. (1956) modified by Gerchacov and Hatcher (1972) for sediments, and concentrations expressed as glucose equivalents. For each analysis blank used sediments were precombusted at $480-500^{\circ} \mathrm{C}$ for 4 hours. Analyses were carried out in triplicate and concentrations were normalized to sediment dry weight. We used the classification proposed by Dell'Anno et al. (2002) based on protein and carbohydrate concentrations to assign different trophic conditions to the 18 sampling locations. These authors defined hypertrophy for protein and carbohydrate concentrations $>4$ and $>7 \mathrm{mg} \mathrm{g}^{-1}$, respectively, eutrophy for protein and carbohydrate concentrations from 1.5 to $4 \mathrm{mg} \mathrm{g}^{-1}$ and from 5 to $7 \mathrm{mg} \mathrm{g}^{-1}$, respectively. Finally, meso-oligotrophy for protein concentrations $<1.5 \mathrm{mg} \mathrm{g}^{-1}$ and carbohydrate concentrations $<5 \mathrm{mg} \mathrm{g}^{-1}$. In addition, three subsamples of $\sim 1.5-2.0 \mathrm{~g}$ were analyzed for total organic matter (TOM) in all stations by weight loss on ignition at $550^{\circ} \mathrm{C}$ for 4 hours following the protocol suggested by Heiri et al. (2001).

\section{Statistics}

For statistical analysis all data were transformed $\log _{10}(x+1)$ to meet parametric criteria. Differences in environmental variables among stations and seasons were investigated by means of two-way ANOVA. When a significant difference for the main effect was observed ( $p<0.05)$, a Tukey's post hoc comparison test was also performed. Cluster analyses were performed for diatom abundance data, using the program PAST version 1.81 (http://folk.uio.no/ohammer/past). Cluster groups were identified using the Morisita method, as recommended when data consist of relative abundances (HAMMER et al., 2008). The significance of the diatom cluster groups was tested by performing ANOSIM on the triangular matrices of Bray Curtis similarity of diatom abundances. The level of significance was calculated from 999 permutations in all cases. A Detrended Canonical Correspondence Analysis (DCCA) was first performed to check that the length of axis $1<2.5 \mathrm{SE}$ units. Then Canonical Correspondence Analysis (CCA) was performed for environmental and diatom data for winter, spring, summer and autumn, using CANOCO for windows (TER BRAAK; SMILAUER, 1998). First, an exploratory analysis was run using all environmental variables. A subset of environmental variables was selected by examination of the variance inflation factor (VIF). Those variables that exhibited a VIF > 10 (i.e., multiple collinear variables) were removed one at a time (WILSON et al., 1994). After each elimination, CCA was re-run and the VIFs were re-examined until no extreme values were observed. The CCA diagram was plotted using CANODRAW, which is available in CANOCO for windows. The significance of the ordination diagram was assessed with the Monte Carlo permutation test using 1000 unrestricted permutations. 


\section{RESULTS}

Bottom Environmental Conditions

Table 1 shows seasonal values of all environmental variables for all stations/seasons that were measured throughout the study, and used in the exploratory ordination analysis. Bottom water temperature and salinity were similar to those of previous studies in the study area, as temperature values ranged between $\sim 7$ and $25^{\circ} \mathrm{C}$, while salinity ranged between 3 (in the internal bay stations) to $\sim 28$ in the adjacent coastal zone. Oxygen saturation values ranged between 50 and $154 \%$ with a mean value of $91 \%$. The lowest values were observed in winter at stations $\mathrm{A}$ and $\mathrm{B}$, and the highest in summer at stations $\mathrm{C}, \mathrm{E}$ and $\mathrm{G}$. Intermediate values were recorded during autumn and spring (Table 1). Silt was the dominant sediment fraction, ranging between $51 \%$ and $80 \%$, except for station $\mathrm{H}$ in autumn when sand was the dominant one. The second most important fraction was sand, which ranged from 5 to $70 \%$.

\section{PhotoSynthetic Pigments and Organic Biopolymers}

Chlorophyll- $a$ concentration in sediments varied from $2.41 \mu \mathrm{g} \mathrm{g}^{-1}$ at station $\mathrm{Q}$ in winter to 22.61 $\mu \mathrm{g} \mathrm{g}^{-1}$ at station $\mathrm{B}$ also in winter (Table $1 \mathrm{~A}$ and $\mathrm{B}$ ). The minimum phaeopigment concentration, $1.72 \mu \mathrm{g}$ $\mathrm{g}^{-1}$, was recorded at station $\mathrm{H}$ in winter, while the maximum (117.51 $\left.\mu \mathrm{g} \mathrm{g}^{-1}\right)$ was observed at station $\mathrm{B}$ in summer (Table 1A and B). Both chlorophyll- $a$ and phaeopigments showed significantly higher values at station B (Tukey's test, $\mathrm{p}<0.01$, Fig. 2A). Chlorophyll- $a$ concentrations were highest in spring, whereas, significantly higher phaeopigment values were recorded in summer and autumn. Total protein concentrations did not display significant temporal changes, but showed significantly higher concentrations at stations B and C (Tukey's test, p < $0.01)$. The maximum protein values for the internal bay stations were recorded at station $\mathrm{B}$ in spring $\left(16.37 \mathrm{mg} \mathrm{g}^{-1}\right)$ and the minimum at station $\mathrm{F}$ in winter ( $3.17 \mathrm{mg} \mathrm{g}^{-1}$, Table $1 \mathrm{~A}$ and $\left.\mathrm{B}\right)$. The adjacent coastal zone exhibited a maximum protein value of $6.78 \mathrm{mg} \mathrm{g}$ 1 at station $\mathrm{J}$ in spring, while the minimum was recorded at station $\mathrm{I}$ in spring (1.08 $\left.\mathrm{mg} \mathrm{g}^{-1}\right)$. Carbohydrates did not display significant differences among stations due to high temporal variability (Table 1). However, mean annual values showed the same trend to that observed for proteins and chloroplastic pigments with highest values at stations $\mathrm{B}$ and $\mathrm{C}$, a decrease towards the outer part of the bay and a high variability in the adjacent coastal zone (Fig. 2). In addition, significant differences were observed between seasons with lower carbohydrate values in winter and autumn. A maximum carbohydrate content of $8.86 \mathrm{mg} \mathrm{g}^{-1}$ in the internal bay was recorded at station $\mathrm{B}$ in spring, and the minimum value was registered at station $\mathrm{F}$ in the winter survey $\left(0.95 \mathrm{mg} \mathrm{g}^{-1}\right)$. The adjacent coastal zone exhibited a maximum carbohydrate concentration of $7.89 \mathrm{mg} \mathrm{g}^{-1}$ at station $\mathrm{O}$ in autumn, whereas the minimum value $\left(0.24 \mathrm{mg} \mathrm{g}^{-1}\right)$ was observed at station $\mathrm{H}$ in winter (Table $1 \mathrm{~A}$ and $\mathrm{B}$ ).

In general, mean annual values of chloroplastic pigments, carbohydrate and protein content showed the same trend, with highest values at the internal bay stations ( $\mathrm{B}$ and $\mathrm{C}$ ). The adjacent coastal zone, on the other hand, exhibited a high variability (Fig. 2). Phaeopigment concentration was always higher than chlorophyll- $a$ (Fig. 2A). According to the carbohydrate data most stations fall into the meso-oligotrophic category and a clear decrease of carbohydrate content was observed from the inner to the outer bay stations. The adjacent coastal zone can be classified as meso-oligotrophic to eutrophic (Fig. 2 $\mathrm{B})$. On the other hand, protein data indicate that most of the bay stations are hypertrophic (A through $\mathrm{G}$ ) and the adjacent coastal zone can be classified as eutrophic to hypertrophic. According to protein data, none of the stations fell into the meso-oligotrophic category (Fig. 2 C).

\section{Diatoms and Dictyochophyceans}

A total of 124 diatom taxa and one dictyochophycean were identified in the study area. The most abundant taxa (i.e. $>3 \%$ at at least three stations, Karst and Smol, 2000) are presented in Figs. 3 through 6. The most abundant species was Aulacoseira granulata, which together with Aulacoseira italica and Aulacoseira muzzanensis (hereafter the Aulacoseira group), accounted for > $30 \%$ and $<70 \%$. Actinocyclus curvatulus and Actinocyclus gallicus were the second most abundant taxa and achieved maximum abundances of $\sim 30 \%$ and minimum abundances of $\sim 15 \%$. Other important but less abundant taxa were Coscinodiscus excentricus, Coscinodiscus radiatus, Hyalodiscus subtilis and Paralia sulcata which displayed values close to $5 \%$. The least abundant taxa were Actinocyclus normanii, Amphora copulata, Cyclotella meneghiniana, Nitzschia linearis, Pleurosira leavis, Pleurosira minor, Staurosira pinnata and Ulnaria ulna. In addition, the dictyochophycean Dichtyocha fibula attained abundance values of $\sim 20 \%$ in some cases.

The stations were grouped by performing cluster analyses for all seasons (Fig. 3 through 6). The ANOSIM results are shown in Table 2. The diatom cluster groups were significant in all cases except for spring, pairwise test between groups 1 and $3(\mathrm{p}=10 \%$, Table 2). 
Table 1A. Seasonal values of recorded environmental variables. The letter to the right of the station's name indicates the season $(\mathrm{W}=$ Winter, $\mathrm{Sp}=$ Spring, $\mathrm{Su}=$ Summer, $\mathrm{A}=$ Autumn $) . \mathrm{Z}=$ depth, $\mathrm{CHO}=$ Carbohydrate, $\mathrm{PRT}=\mathrm{Protein}$, $\mathrm{BT}=$ Bottom Temperature, BOS = Bottom Oxygen Saturation, BpH, Bottom pH, BS = Bottom Salinity, OM = Organic Matter, Chl-a = Chlorophyll-a. Values given between brackets represent $+/-\mathrm{SE}$.

\begin{tabular}{|c|c|c|c|c|c|c|c|c|c|c|c|c|}
\hline Station & $\begin{array}{c}\mathrm{Z} \\
(\mathrm{m})\end{array}$ & $\underset{\left(\mathrm{mg} \mathrm{g}^{-1}\right)}{\mathrm{CHO}}$ & $\underset{\left(\mathrm{mg} \mathrm{g}^{-1}\right)}{\mathrm{PRT}}$ & $\begin{array}{l}\mathrm{BT} \\
\left({ }^{\circ} \mathrm{C}\right)\end{array}$ & $\begin{array}{l}\text { BOS } \\
(\%)\end{array}$ & $\mathrm{BpH}$ & BS & $\mathrm{OM}(\%)$ & $\begin{array}{c}\text { Chl-a } \\
\left(\mu \mathrm{g} \mathrm{g}^{-1}\right)\end{array}$ & $\begin{array}{l}\text { Sand } \\
(\%)\end{array}$ & $\begin{array}{l}\text { Silt } \\
(\%)\end{array}$ & $\begin{array}{l}\text { Clay } \\
(\%)\end{array}$ \\
\hline $\mathrm{A} \mathrm{W}$ & 1 & $1.62(0.7)$ & $9.01(0.1)$ & 7 & 53.1 & 7.4 & 4.7 & $7.6(1.4)$ & $4.6(3.2)$ & 31.54 & 52.75 & 15.71 \\
\hline A Sp & 1.4 & $6.85(0.3)$ & $8.37(1.9)$ & 21 & 99.3 & 8.6 & 4.4 & $8.0(1.5)$ & $9.6(0.8)$ & 62.59 & 31.99 & 5.42 \\
\hline A Su & 1.2 & $2.78(0.3)$ & $7.03(0.2)$ & 24.9 & 102.3 & 7.9 & 27.2 & $8.4(1.9)$ & $10.9(4.5)$ & 14.51 & 68.13 & 17.36 \\
\hline A A & 1.3 & $4.03(0.7)$ & $7.08(0.1)$ & 16.8 & 67.7 & 7.9 & 4.0 & $11.6(1.5)$ & $11.5(2.1)$ & 62.4 & 30.47 & 7.09 \\
\hline B W & 1.2 & $6.64(0.7)$ & $13.09(1.3)$ & 10 & 50.1 & 7.4 & 7.1 & $6.7(0.7)$ & $22.6(11.2)$ & 23.55 & 66.1 & 10.35 \\
\hline B Sp & 1 & $8.86(1.2)$ & $16.37(1.6)$ & 21.5 & 64.5 & 8.1 & 5.4 & $12.5(2.9)$ & $13.9(7.7)$ & 27.72 & 62.06 & 10.22 \\
\hline B Su & 1 & $6.29(1.2)$ & $9.86(0.3)$ & 25.5 & 141.0 & 8.1 & 27.5 & $8.2(1.3)$ & $23.1(7.5)$ & 29.24 & 61.14 & 9.62 \\
\hline B A & 1.5 & $4.21(1.0)$ & $8.87(0.3)$ & 17 & 91.2 & 7.7 & 3.7 & $12.5(2.3)$ & $21.4(7.0)$ & 50.44 & 43.71 & 5.85 \\
\hline $\mathrm{CW}$ & 1 & $4.32(1.3)$ & $4.87(0.3)$ & 7 & 68.6 & 7.8 & 7.8 & $7.8(1.2)$ & $7.9(0.6)$ & 36.09 & 53.5 & 10.61 \\
\hline C Sp & 1.2 & $3.45(0.5)$ & $9.18(0.2)$ & 21.5 & 91.1 & 8.2 & 4.7 & $10.4(1.0)$ & $10.2(3.13)$ & 35.54 & 53.96 & 10.5 \\
\hline $\mathrm{C} \mathrm{Su}$ & 1.2 & $8.49(0.6)$ & $15.25(0.3)$ & 24.4 & 154.3 & 8.3 & 27.2 & $9.2(2.0)$ & $12.4(8.2)$ & 11.19 & 74.11 & 14.7 \\
\hline $\mathrm{CA}$ & 1.2 & $6.79(0.8)$ & $9.63(0.2)$ & 17 & 65.7 & 7.6 & 3.7 & $10.6(4.5)$ & $5.4(1.1)$ & 50.57 & 41.12 & 8.31 \\
\hline D W & 3 & $6.53(0.4)$ & $9.01(0.4)$ & 7 & 73.5 & 7.6 & 7.2 & $8.7(3.6)$ & $7.6(4.8)$ & 39.21 & 50.36 & 10.43 \\
\hline D Sp & 1.6 & $1.56(0.7)$ & $7.00(0.6)$ & 21 & 90.6 & 8.4 & 5.5 & $8.1(1.0)$ & $14.6(1.4)$ & 31.54 & 55.47 & 12.99 \\
\hline D Su & 1.6 & $1.71(0.5)$ & $6.61(0.3)$ & 22.7 & 131.1 & 8.1 & 27.8 & $8.7(2.7)$ & $7.2(2.0)$ & 20.07 & 66.41 & 13.52 \\
\hline D A & 3 & $6.03(0.3)$ & 12.10 & 17 & 78.4 & 7.7 & 3.5 & $11.0(1.7)$ & $6.2(1.0)$ & 45.35 & 44.74 & 9.9 \\
\hline E W & 1.8 & $1.60(0.3)$ & $5.61(0.2)$ & 7.5 & 67.0 & 7.7 & 8.3 & $5.3(0.3)$ & $13.9(2.1)$ & 37.14 & 53.53 & 9.33 \\
\hline E Sp & 1.5 & $5.95(2.4)$ & $7.50(2.0)$ & 22 & 134.0 & 8.6 & 4.1 & $7.7(0.5)$ & $8.0(3.9)$ & 28.63 & 62.67 & 8.7 \\
\hline E Su & 3 & $2.60(0.2)$ & $4.44(0.3)$ & 23.3 & 140.4 & 8.3 & 25.1 & $4.9(1.4)$ & $10.4(2.8)$ & 47.21 & 46.72 & 6.07 \\
\hline E A & 2.5 & $2.47(0.7)$ & $8.40(1.5)$ & 17 & 95.2 & 7.7 & 3.2 & $3.6(0.8)$ & $11.0(1.9)$ & 56.38 & 40.24 & 3.38 \\
\hline $\mathrm{FW}$ & 2 & $0.94(0.5)$ & $3.17(0.4)$ & 7.5 & 78.9 & 7.8 & 7.4 & $7.7(0.4)$ & $13.9(0.4)$ & 29.33 & 62.79 & 7.88 \\
\hline $\mathrm{FSp}$ & 2.5 & $1.60(0.2)$ & $3.19(0.1)$ & 21.5 & 100.3 & 8.6 & 4.6 & $7.2(0.6)$ & $10.7(2.4)$ & 56.6 & 39.75 & 3.65 \\
\hline F Su & 2.9 & $2.50(0.5)$ & $4.97(0.1)$ & 26.1 & 88.5 & 7.8 & 26.2 & $7.2(1.6)$ & $10.4(3.5)$ & 9.86 & 74.85 & 15.29 \\
\hline $\mathrm{FA}$ & 2.8 & $5.46(0.4)$ & $7.18(0.2)$ & 17.1 & 80.7 & 7.6 & 3.5 & $10.1(3.3)$ & $6.4(1.2)$ & 47.17 & 47.24 & 5.58 \\
\hline G W & 3 & $2.28(1.4)$ & $3.70(0.7)$ & 7.5 & 73.9 & 7.9 & 7.9 & $5.0(0.9)$ & $5.6(1.2)$ & 17.88 & 75.49 & 6.63 \\
\hline G Sp & 2.8 & $4.80(1.7)$ & $4.39(0.2)$ & 20.6 & 98.3 & 8.1 & 6.1 & $5.8(0.8)$ & $7.0(2.0)$ & 37.12 & 57.12 & 5.76 \\
\hline G Su & 3.2 & $0.83(2.1)$ & $5.29(0.1)$ & 23.3 & 140.4 & 8.2 & 25.1 & $8.8(2.8)$ & $3.9(3.0)$ & 25.22 & 65.48 & 9.3 \\
\hline G A & 3.5 & $1.82(0.7)$ & $5.20(0.4)$ & 17.1 & 84.8 & 7.9 & 3.2 & $7.5(2.4)$ & $5.0(3.0)$ & 34.21 & 60.83 & 4.96 \\
\hline $\mathrm{HW}$ & 2.5 & $0.23(0.3$ & $1.45(0.2)$ & 8 & 69.4 & 7.9 & 8.5 & $4.3(3.5)$ & $10.1(12.3)$ & 81.05 & 13.8 & 5.15 \\
\hline H Sp & 3.1 & $5.0(2.5)$ & $4.83(0)$ & 21 & 77.6 & 8.2 & 7.5 & $7.7(0.4)$ & $12.3(4.5)$ & 40.9 & 52.06 & 7.04 \\
\hline $\mathrm{H} \mathrm{Su}$ & 2 & $1.32(0.9)$ & $4.04(0.2)$ & 23.7 & 111.7 & 8.0 & 27.7 & $5.6(1.4)$ & $8.3(1.5)$ & 44.83 & 42.77 & 12.4 \\
\hline $\mathrm{HA}$ & 3 & $2.37(0.4)$ & $2.47(0.1)$ & 15.5 & 77.4 & 7.8 & 4.4 & $3.8(1.3)$ & $2.6(1.1)$ & 73.59 & 23.53 & 2.88 \\
\hline I W & 4.5 & $4.95(0.8)$ & $5.80(0.3)$ & 8 & 75.1 & 8 & 10.5 & $8.0(2.1)$ & $9.3(2.9)$ & 38.83 & 54.82 & 6.35 \\
\hline I Sp & 4.6 & $4.82(0.6)$ & $1.08(0.1)$ & 21 & 70.2 & 8 & 6.8 & $9.4(0.3)$ & $14.6(6.4)$ & 31.42 & 59.34 & 9.24 \\
\hline I Su & 5.2 & $3.64(0.4)$ & $3.10(0.9)$ & 21.2 & 85.6 & 8.0 & 27.5 & $9.8(0.6)$ & $5.6(1.6)$ & 5.74 & 81.88 & 12.38 \\
\hline I A & 4.7 & $4.06(1.0)$ & $5.48(0.1)$ & 17.2 & 84.0 & 7.7 & 5.6 & $12.0(2.8)$ & $3.6(1.3)$ & 40.39 & 54.18 & 5.43 \\
\hline $\mathrm{JW}$ & 4.5 & $4.37(0.1)$ & $4.36(0.1)$ & 8 & 78.8 & 8 & 23.6 & $8.2(0.9)$ & $6.9(1.6)$ & 31.75 & 61.56 & 6.69 \\
\hline $\mathrm{J} S \mathrm{Sp}$ & 4.2 & $5.23(0.6)$ & $6.78(0.2)$ & 22 & 89.7 & 8.2 & 5.0 & $8.4(0.3)$ & $12.2(2.3)$ & 25.64 & 65.59 & 8.77 \\
\hline $\mathrm{J} \mathrm{Su}$ & 5 & $1.13(0.5)$ & $2.37(0.4)$ & 21.2 & 121.5 & 7.9 & 28.0 & $9.0(1.5)$ & $6.1(3.3)$ & 12.99 & 68.34 & 18.67 \\
\hline $\mathrm{J}$ A & 4.5 & $4.55(0.6)$ & $2.20(0.1)$ & 17.2 & 89.7 & 7.7 & 4.1 & $8.1(2.2)$ & $10.6(5.5)$ & 45.25 & 49.81 & 4.94 \\
\hline K W & 6.3 & $3.87(1.0)$ & $4.49(0.2)$ & 7.5 & 84.5 & 8 & 26.8 & $8.6(0.6)$ & $5.3(0.2)$ & 16.75 & 72.38 & 10.87 \\
\hline K Sp & 6.5 & 7.87 (1.3) & $2.91(2.7)$ & 21 & 87.5 & 8.2 & 6.2 & $7.6(1.6)$ & $10.8(4.1)$ & 50.01 & 46 & 3.99 \\
\hline $\mathrm{K} \mathrm{Su}$ & 7.3 & $4.86(0.6)$ & $4.74(0.2)$ & 20.1 & 119.3 & 7.9 & 28.2 & $6.4(2.5)$ & $4.4(1.3)$ & 11.28 & 74.42 & 14.3 \\
\hline $\mathrm{KA}$ & 7.5 & $5.04(0.3)$ & $3.39(0.5)$ & 17.1 & 94.3 & 7.5 & 10.9 & $4.8(1.9)$ & $9.9(4.1)$ & 21.92 & 67.99 & 10.09 \\
\hline LW & 7 & $5.43(0.3)$ & $4.78(0.2)$ & 7 & 81.5 & 8 & 24.8 & $6.0(1.0)$ & $5.0(1.9)$ & 31.05 & 60.61 & 8.34 \\
\hline $\mathrm{LSp}$ & 7.3 & $1.59(3.4)$ & $2.33(0.7)$ & 19 & 76.2 & 7.8 & 8.7 & $6.5(1.1)$ & $14.1(2.1)$ & 26.91 & 63.44 & 9.65 \\
\hline $\mathrm{L} \mathrm{Su}$ & 6.5 & $4.38(0.4)$ & $3.78(0.2)$ & 21.1 & 123.7 & 8.2 & 28.4 & $4.3(2.1)$ & $4.8(1.4)$ & 9.17 & 75.31 & 15.52 \\
\hline $\mathrm{LA}$ & 7 & $6.27(1.4)$ & $5.96(0.2)$ & 17.1 & 79.0 & 7.7 & 9.0 & $10.2(1.6)$ & $8.4(2.3)$ & 36.46 & 57.56 & 5.98 \\
\hline $\mathrm{MW}$ & 6 & $3.67(0.7)$ & - & 7.5 & 83.8 & 8 & 25.6 & $4.8(0.9)$ & $10.7(9.2)$ & 9.54 & 75.7 & 14.76 \\
\hline M Sp & 7.5 & $5.13(0.7)$ & $2.24(0.4)$ & 20 & 75.6 & 8.2 & 8.9 & $7.8(2.1)$ & $12.9(5.7)$ & 28.52 & 61.98 & 9.5 \\
\hline $\mathrm{MA}$ & 7.9 & $7.75(0.6)$ & $5.18(0.1)$ & 17 & 92.3 & 7.6 & 15.7 & $7.9(5.0)$ & $10.4(2.4)$ & 39.03 & 54.73 & 6.24 \\
\hline $\mathrm{NW}$ & 4.5 & $1.58(0.4)$ & $4.52(0.2)$ & 8.2 & 83.6 & 7.9 & 24.5 & $7.1(0.3)$ & $5.9(2.4)$ & 20.2 & 68.53 & 11.27 \\
\hline N Sp & 4.7 & $3.03(1.6)$ & $6.73(0.4)$ & 21 & 81.8 & 8 & 6.5 & $6.5(1.0)$ & $8.9(1.6)$ & 32.51 & 60.14 & 7.35 \\
\hline N Su & 4.7 & $4.42(3.3)$ & $3.93(0.5)$ & 23.6 & 101.8 & 7.8 & 24.6 & $5.7(2.3)$ & $8.5(2.5)$ & 9.72 & 72.47 & 17.81 \\
\hline N A & 4.9 & $4.0(1.3)$ & $5.89(0.1)$ & 17 & 101.6 & 8.1 & 3.4 & $5.2(1.8)$ & $10.9(0.7)$ & 44.56 & 49.87 & 5.58 \\
\hline $\mathrm{OW}$ & 4.5 & $2.23(1.5)$ & $4.03(0.6)$ & 8 & 82.0 & 7.8 & 18.6 & $5.7(0.4)$ & $5.9(3.2)$ & 12.97 & 76.66 & 10.37 \\
\hline O Sp & 4.7 & $4.34(0.8)$ & $3.07(0.3)$ & 21 & 68.4 & 8 & 8.1 & $7.0(1.1)$ & $8.4(3.0)$ & 31.3 & 63.08 & 5.79 \\
\hline O Su & 4.8 & $5.89(1.0)$ & $4.48(0.2)$ & 23.1 & 112.5 & 7.8 & 27.9 & $6.6(3.2)$ & $7.1(3.0)$ & 9.63 & 73.54 & 16.83 \\
\hline $\mathrm{OA}$ & 4.7 & $7.89(0.7)$ & $6.41(0.4)$ & 17 & 96.2 & 8.1 & 3.2 & $5.6(1.9)$ & $11.9(5.3)$ & 37.01 & 55.69 & 7.3 \\
\hline $\mathrm{PW}$ & 6 & $1.90(0.3)$ & $4.60(0.1)$ & 8.5 & 79.6 & 8 & 23.4 & $4.7(3.5)$ & $5.1(2.7)$ & 21.32 & 69 & 9.68 \\
\hline P Sp & 5 & $4.20(2.0)$ & $3.26(1.6)$ & 23 & 104.3 & 8.6 & 4.4 & $9.1(0.6)$ & $9.3(1.1)$ & 29.11 & 63.31 & 7.58 \\
\hline $\mathrm{PSu}$ & 6.2 & $5.40(2.2)$ & $3.36(0.6)$ & 25.4 & 94.6 & 7.9 & 28.1 & $7.2(3.0)$ & $3.9(2.1)$ & 10.6 & 76.79 & 12.61 \\
\hline $\mathrm{PA}$ & 6 & $4.49(1.4)$ & $5.09(0.8)$ & 17 & 82.9 & 7.9 & 4.0 & $9.0(3.5)$ & $4.9(1.8)$ & 42.67 & 52 & 5.33 \\
\hline Q W & 6 & $1.49(0.5)$ & $4.86(0.4)$ & 7.9 & 83.1 & 8 & 24.6 & $4.4(1.6)$ & $2.4(0.4)$ & 14.06 & 74.91 & 11.03 \\
\hline $\mathrm{Q} S \mathrm{p}$ & 6.1 & 2.94 (1.8) & $2.22(0.7)$ & 23 & 96.9 & 8.9 & 3.9 & $8.2(2.5)$ & $16.0(1.6)$ & 25.72 & 66.9 & 7.38 \\
\hline Q Su & 7.4 & $5.73(1.3)$ & $4.23(0.4)$ & 22.9 & 118.9 & 7.9 & 27.9 & $7.4(3.7)$ & $5.9(1.1)$ & 8.67 & 77.89 & 13.44 \\
\hline Q A & 7.1 & $4.38(0.8)$ & $4.07(0.9)$ & 17 & 98.21 & 7.8 & 4.8 & $7.5(2.0)$ & $6.6(2.6)$ & 29.46 & 64.49 & 6.05 \\
\hline $\mathrm{RW}$ & 6 & $2.10(0.3)$ & $3.83(0.1)$ & 8 & 74.8 & 8 & 25.5 & $4.1(0.5)$ & $7.7(3.0)$ & 32.4 & 60.73 & 6.87 \\
\hline R Sp & 6.1 & - & - & 22 & 75.6 & 8.2 & 5.1 & $6.2(1.5)$ & $9.8(2.4)$ & 21.83 & 68.49 & 9.68 \\
\hline R Su & 7.1 & $3.56(1.5)$ & $4.87(0.5)$ & 24 & 101.9 & 7.9 & 27.9 & $5.4(2.4)$ & $4.4(0.5)$ & 5.69 & 79.8 & 14.51 \\
\hline R A & 7.1 & $5.06(1.1)$ & $5.0(0.1)$ & 17 & 87.4 & 7.7 & 6.5 & $9.7(0.9)$ & $6.1(2.9)$ & 30.06 & 63.12 & 6.82 \\
\hline
\end{tabular}



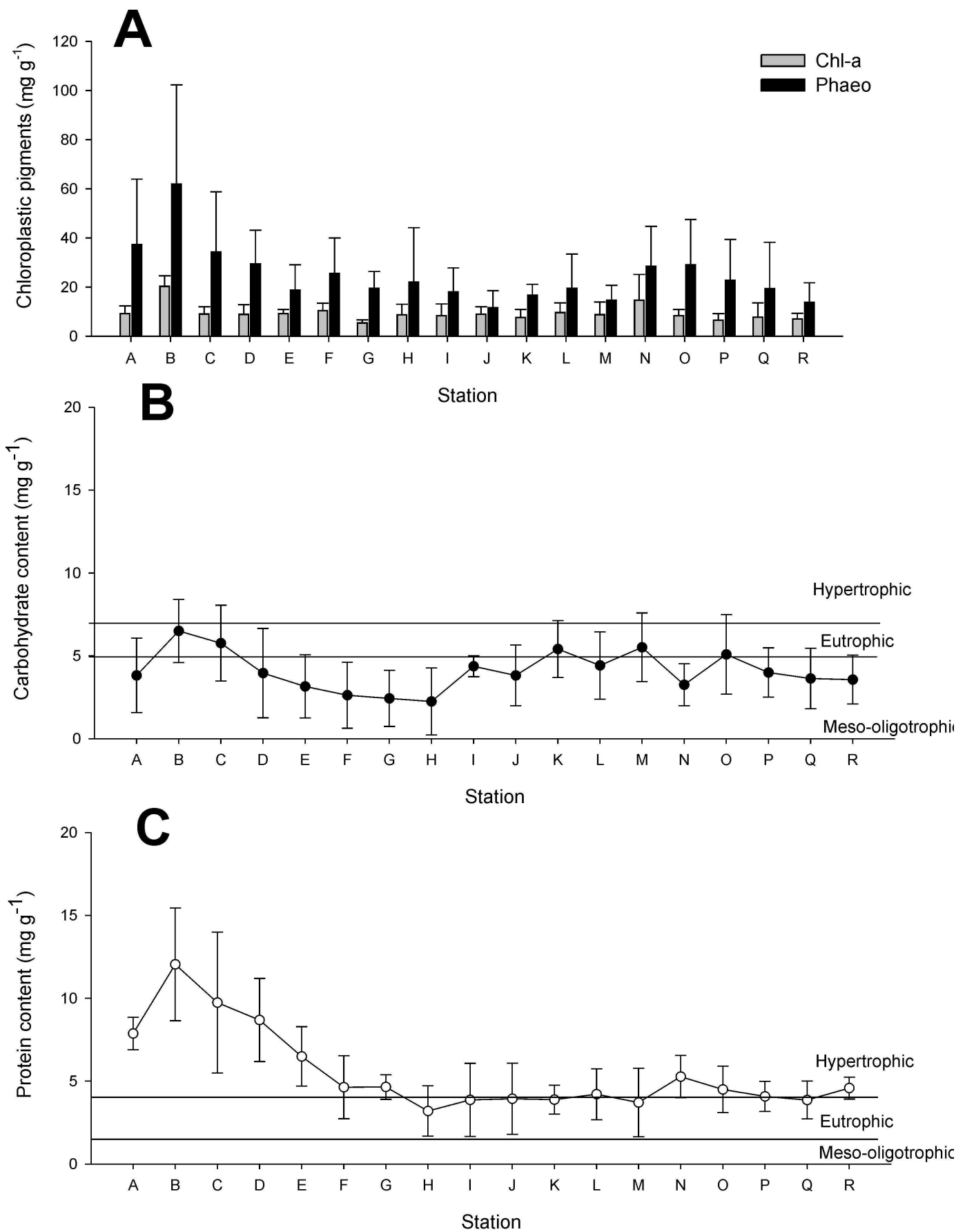

Fig. 2. Mean annual (+SE) photosynthetic pigment concentration (A), mean annual (+SE) sediment carbohydrate content (B), mean annual (+SE) sediment protein content (C; The trophic categories defined by Dell'anno (2002) are indicated with dashed lines on both B and C. 


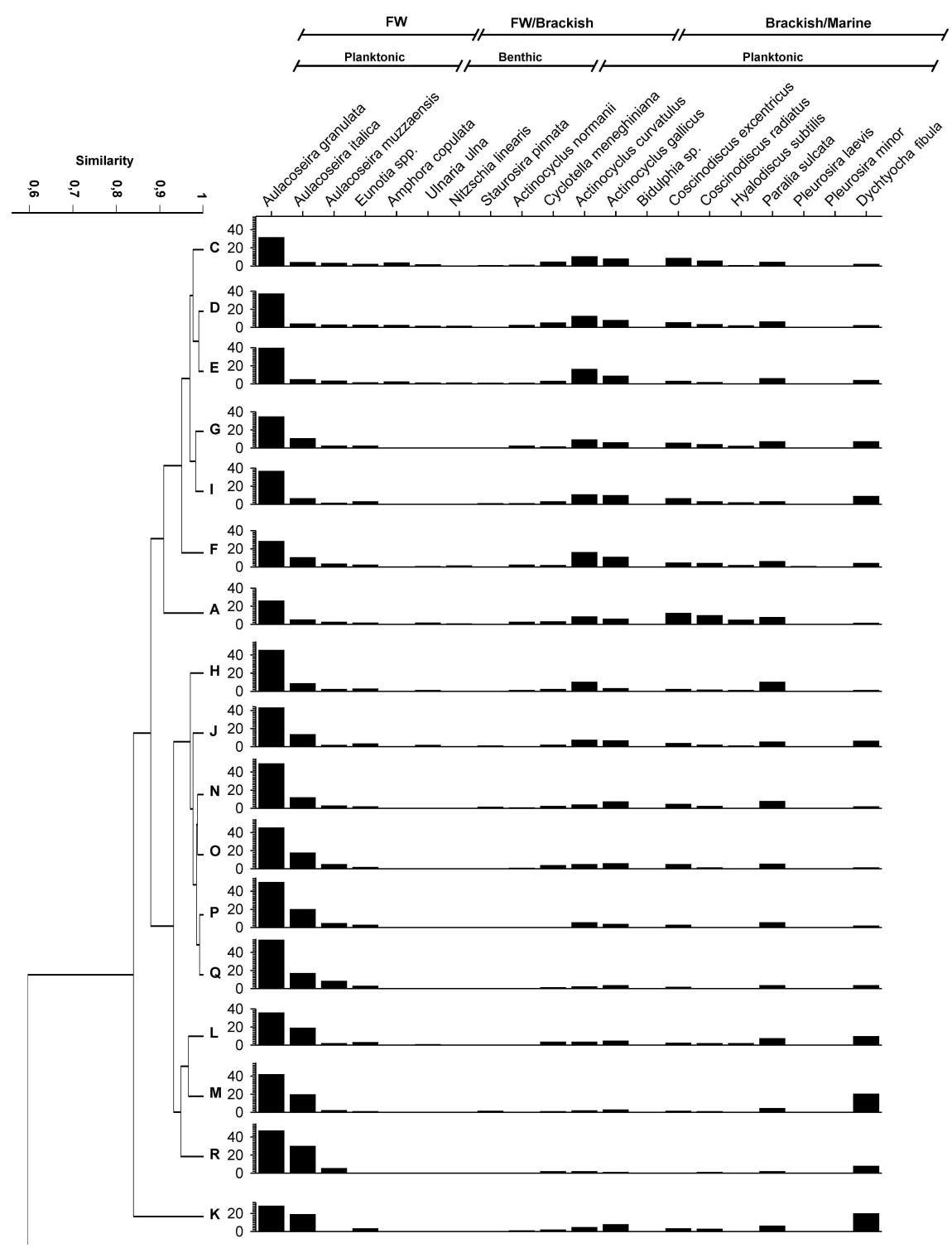

Fig. 3. Left: winter cluster analysis of diatom data. Right: diatom relative abundances for each of the stations (A through R). The ecological preferences of the diatoms are indicated on the top graph.

Table 2. ANOSIM results for the diatom groups identified in the cluster analyses presented in figures 3 to 6 . A number of 999 permutations was used in all cases.

\begin{tabular}{|c|c|c|c|c|}
\hline Season & Group of stations & $\begin{array}{c}\mathrm{R} \text { global and } \\
\text { probability }(\%)\end{array}$ & $\mathrm{N}^{\circ}$ of permuations & $\begin{array}{c}\text { Pairwise test } \\
\mathrm{R} \text { and probability }(\%)\end{array}$ \\
\hline Winter & $\begin{array}{l}\text { Group 1: A, C through } \mathrm{G} \text { and I } \\
\text { Group 2: } \mathrm{H}, \mathrm{J}, \mathrm{L} \text { through } \mathrm{R}\end{array}$ & $0.745 ; \mathrm{p}=0.1 \%$ & higher than or equal to Global R: 0 & \\
\hline Spring & $\begin{array}{l}\text { Group 1: B, C, E } \\
\text { Group 2: D, F through O, K, R } \\
\text { Group 3: P, A }\end{array}$ & $0.979 ; p=0.1 \%$ & higher than or equal to Global R: 0 & $\begin{array}{l}\mathrm{R}_{1,2}=1.0 ; \mathrm{p}=0.2 \% \\
\mathrm{R}_{1,3}=0.667 ; \mathrm{p}=10 \% \\
\mathrm{R}_{2,3}=0.965 ; \mathrm{p}=1 \%\end{array}$ \\
\hline Summer & $\begin{array}{l}\text { Group 1: B, C, N, O } \\
\text { Group 2: D, F through I; } \\
\text { Group 3: A, L, P through R }\end{array}$ & $0.699 ; p=0.1 \%$ & higher than or equal to Global R: 0 & $\begin{array}{l}\mathrm{R}_{1,2}=0.831 ; \mathrm{p}=0.8 \% \\
\mathrm{R}_{1,3}=0.663 ; \mathrm{p}=0.8 \% \\
\mathrm{R}_{2,3}=0.812 ; \mathrm{p}=0.8 \%\end{array}$ \\
\hline Autumn & $\begin{array}{l}\text { Group 1: A, B, C, K, N } \\
\text { Group 2: D, F through J, L, M, O through R }\end{array}$ & $0.571 ; \mathrm{p}=0.4 \%$ & higher than or equal to Global R: 3 & \\
\hline
\end{tabular}


Cluster analysis identified two main station groups for winter. The upper section of the dendrogram (Fig. 3) consisted of stations C through G, $\mathrm{A}$ and $\mathrm{I}$, where the most abundant diatom species were the Aulacoseira group, with Actinocyclus curvatulus, Actinocyclus gallicus, Coscinodiscus excentricus, Coscinodiscus radiatus, Hyalodiscus subtilis and Paralia sulcata as co-dominant species. The middle section of the cluster grouped the stations of the adjacent coastal zone (i.e., $\mathrm{H}, \mathrm{J}$ and $\mathrm{L}$ through R) showed very high relative abundances of the
Aulacoseira (ca. 70\%). Stations K and B were grouped in the lower section of the diagram.

In spring, two main station groups were indentified. The first, in the upper section of the dendrogram, comprised stations B, C and E located within the bay (Fig. 4), where the Aulacoseira group abundances accounted together for slightly more than $60 \%$, and co-dominance of Actinocyclus curvatulus and Actinocyclus gallicus was observed. Stations D, F through $\mathrm{O}, \mathrm{Q}$ and $\mathrm{R}$ were distinguished because they displayed the highest values of the Aulacoseira granulata, which in most cases were close to $60 \%$.

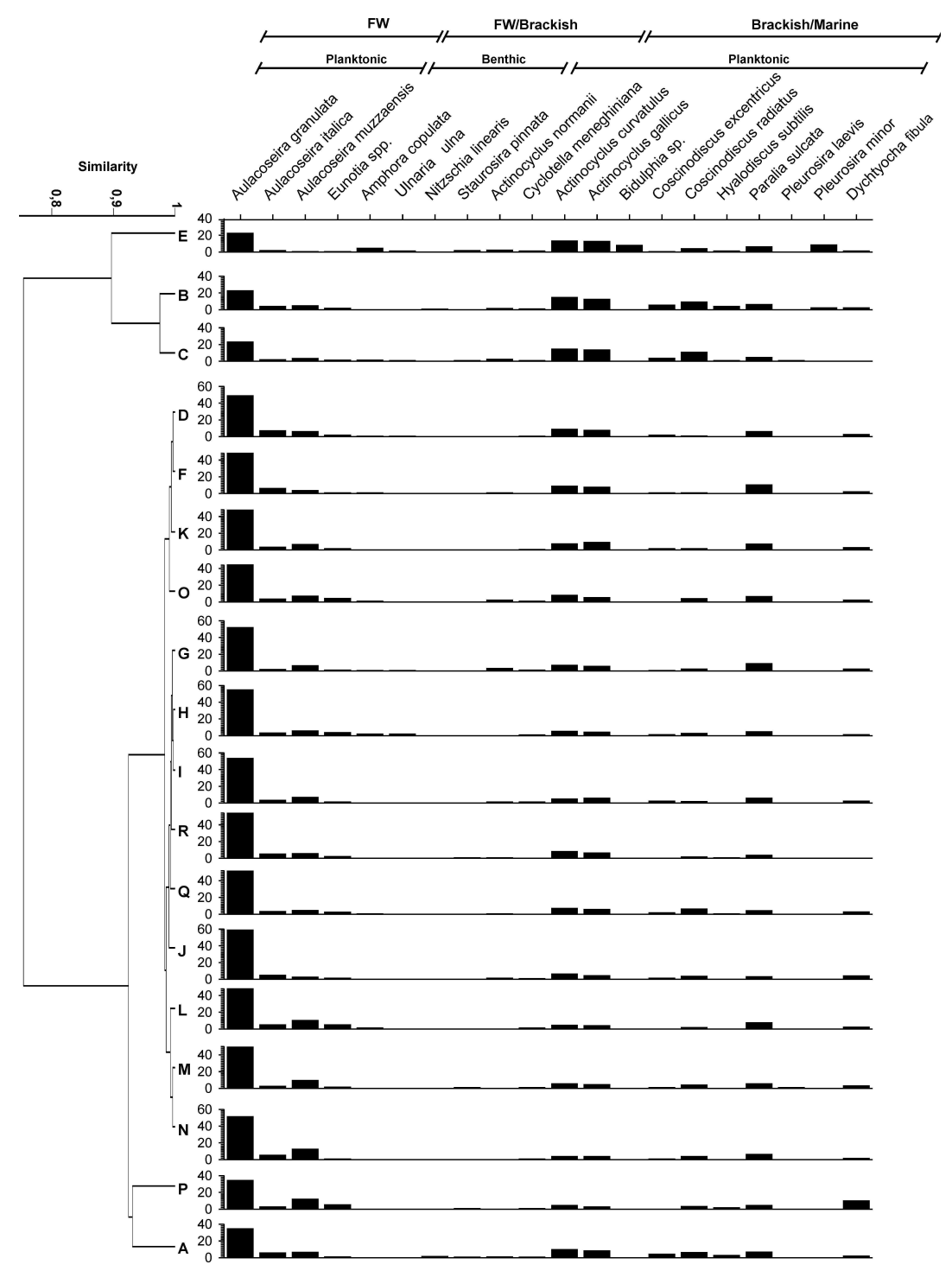

Fig. 4. Left: spring cluster analysis of diatom data. Right: diatom relative abundances for each of the stations (A through R). The ecological preferences of the diatoms are indicated on the top graph. 
In summer, the upper section of the cluster diagram consisted of stations $\mathrm{B}, \mathrm{C}, \mathrm{N}$ and $\mathrm{O}$, which were distinguished because the Aulacoseira group attained fairly similar values to those of Actinocyclus curvatulus and Actinocyclus gallicus (Fig. 5). Station D and stations F through I, showed Aulacoseira group percentages of $\sim 50$ to $60 \%$, and the co-dominant taxa were Actinocyclus curvatulus, Actinocyclus gallicus, Actinocyclus normanii, Hyalodiscus subtilis and Coscinodiscus radiatus. In stations $\mathrm{A}, \mathrm{L}$ and $\mathrm{P}$ through $\mathrm{R}$ the abundance values of the Aulacoseira group were $\sim 30 \%$, co-dominant species were similar to those mentioned above, but both Actinocyclus normanii and Cyclotella meneghiniana were absent. Stations E, J and $\mathrm{K}$ were grouped separately. Station E showed high abundance values of Eunotia spp. ( 20\%), at station J relatively high abundances of Dichtyocha fibula were observed, while in station $\mathrm{K}$ the Aulacoseira group accounted for almost $70 \%$.
In autumn, station $\mathrm{E}$ (upper section of the dendrogram, Fig. 6) showed very low abundance values of the Aulacoseira group, while Amphora copulata and Biddulphia sp. were the most abundant diatoms. Co-dominance of both Pleurosira minor and Pleurosira laevis was observed. Stations A, B, C, K and $\mathrm{N}$ (i.e., lower section of the dendrogram in Fig. 6), were characterized by the relatively low percentage values of the Aulacoseira group, with similar abundance values of Actinocyclus gallicus and Actinocyclus curvatulus, but also Coscinodiscus radiatus and Hyalodiscus subtilis, accounted together for $\sim 20 \%$. The remaining stations (i.e., D, F through J, $\mathrm{L}$ and $\mathrm{M}$, and $\mathrm{O}$ through $\mathrm{R}$ ) displayed the highest Aulacoseira group values with co-dominance of Actinocyclus gallicus and Actinocyclus curvatulus. In addition the highest abundances of Dichtyocha fibula were recorded.

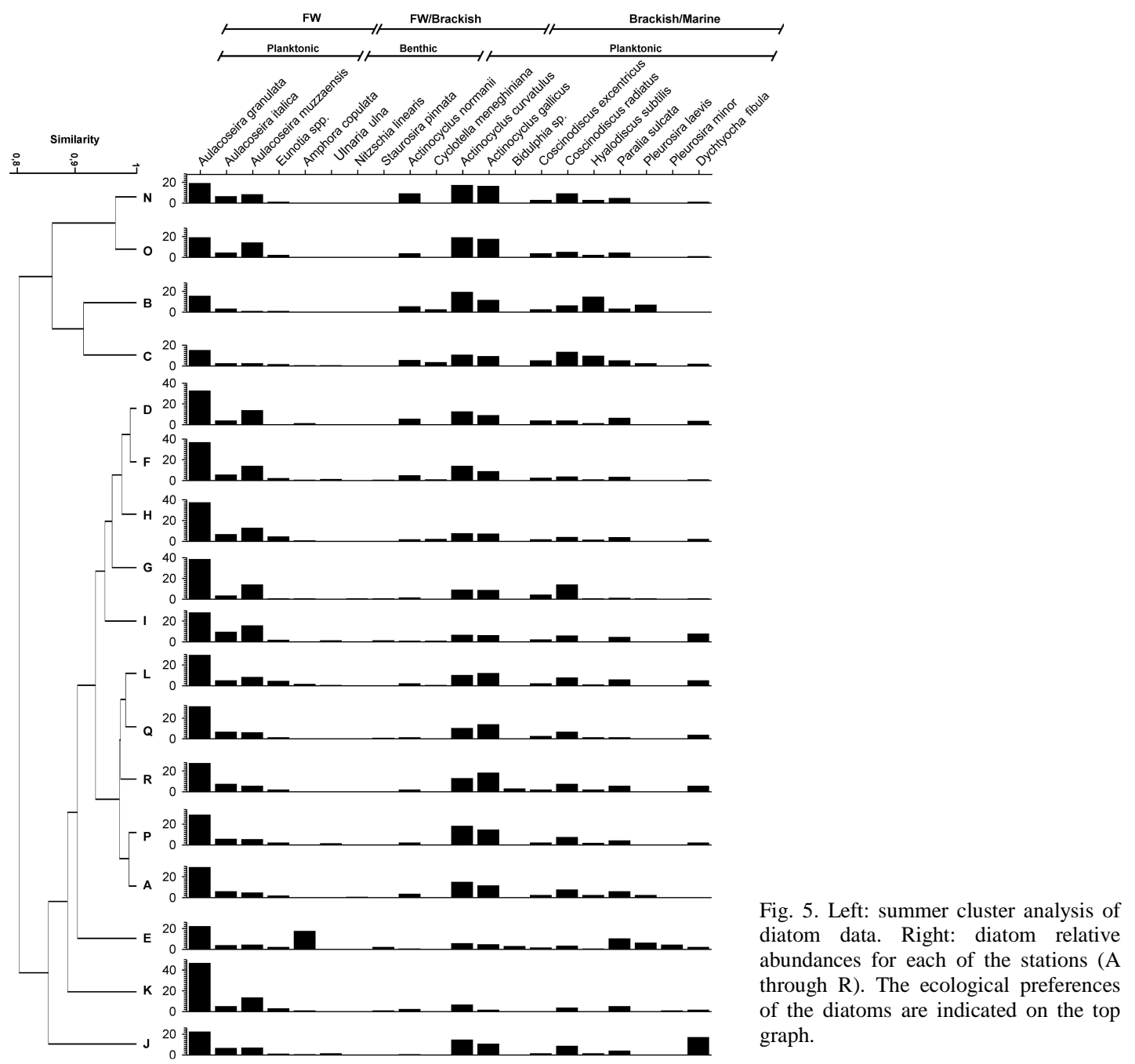




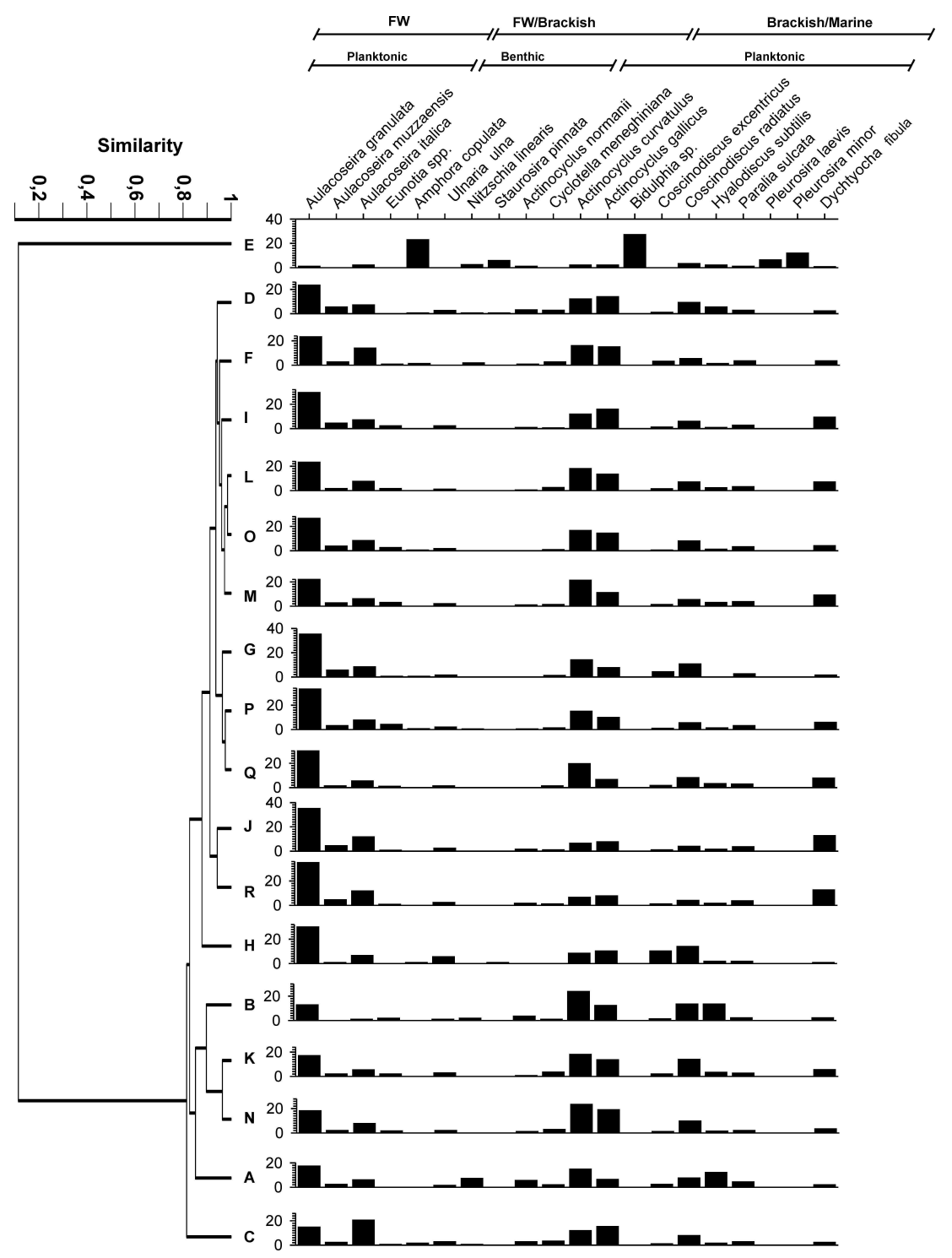

Fig. 6. Left: autumn cluster analysis of diatom data. Right: diatom relative abundances for each of the stations (A through R). The ecological preferences of the diatoms are indicated on the top graph.

Ordination Analysis

Figure 7 shows the distribution of the stations, diatom species and environmental variables within the CCA triplot ordination diagram, considering data of the four surveys carried out in the present study. The test of Monte Carlo indicated that the ordination diagram was significant $(\mathrm{F}=3.537, \mathrm{p}<$ $0.05)$, and the relationship species-environmental data of the first two ordination axes (axis $1 \lambda=0.067$; axis $2 \lambda=0.017)$ explained $81.9 \%$ of the variance. From the eleven variables shown in Table $1 \mathrm{~A}$ and $\mathrm{B}$, only bottom salinity, organic matter, carbohydrate and protein content were utilized in the multivariate analysis, as variance inflation factors were lower than 10. According to these data, axis 1 represents a clear gradient from the internal bay stations to the adjacent coastal zone, where the highest values of organic matter, carbohydrate and protein content were observed in the bay. The identified species related to such conditions were Actinocyclus curvatulus, Actinocyclus gallicus; Actinocyclus normanii, 
Amphora copulata, Coscinodiscus excentricus, Coscinodiscus radiatus, Cyclotella meneghiniana, Hyalodiscus subtilis, Nitzschia linearis and Ulnaria ulna. On the other hand, axis 2 indicates that there is also a bottom salinity gradient from the adjacent coastal zone towards Montevideo Bay. The highest salinity levels were observed in the adjacent coastal zone during summer and the lowest in the internal bay during winter.

\section{DisCUSSION}

The environmental data indicate that the water temperature ranges correspond to those of the temperate zone, which exhibit estuarine myxohaline conditions, and either neutral to moderately alkaline levels. The waters are mostly well oxygenated except for the internal bay stations in winter, where the waters showed under-saturation levels, which could be attributed to contamination (DESA et al., 2005). Super-saturation oxygen levels were observed in summer, most probably due to high primary productivity rate (GÓMEZ et al., 2001). Sediment distribution is in accordance with the general pattern determined for the Río de la Plata Estuary (LÓPEZLABORDE, 1997). The most heterogeneous sediments are those of the innermost part of the bay, most probably because of the influence of both Pantanoso and Miguelete Streams, which contribute with considerable amounts of sand. This fact had also been observed by Burone et al. (2006), Venturini et al. (2004) and Muniz et al. (2002, 2004a, b).

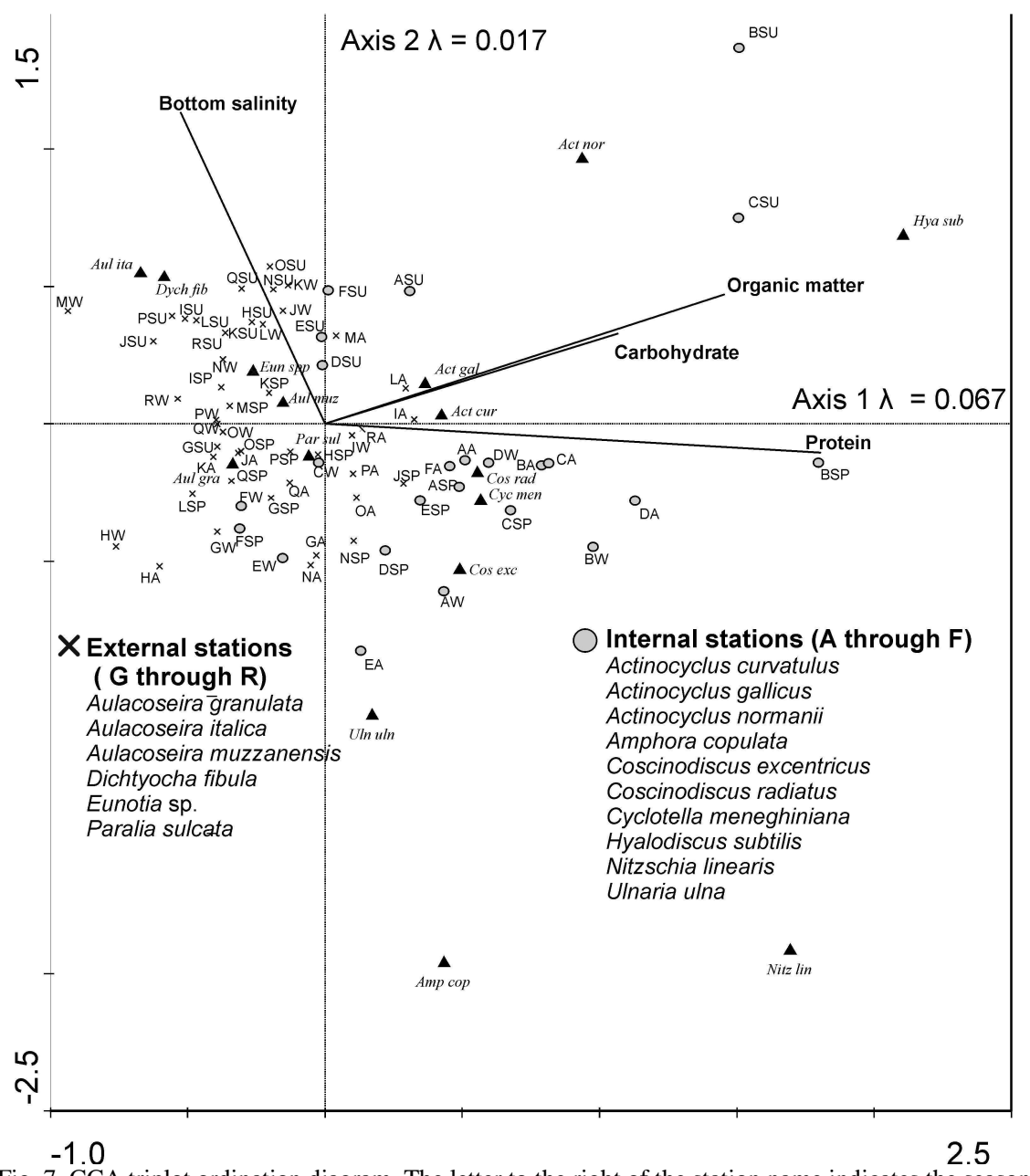

Fig. 7. CCA triplot ordination diagram. The letter to the right of the station name indicates the season (W= Winter, $\mathrm{Sp}=$ Spring, $\mathrm{Su}=$ Summer, $\mathrm{A}=$ Autumn). 
Montevideo coastal zone displayed elevated organic matter percentages similar to those reported in other urban and industrial areas in the world (DELL'ANNO et al., 2002; BIGOT et al., 2006). In addition, photosynthetic pigment contents registered in sediments from Montevideo are comparable to those reported in highly productive systems considered as eutrophic, but also in areas influenced by anthropogenic activities (BOON et al., 1998). Moreover, the chloroplastic pigment values recorded in the present study are higher than those previously reported in this area (MUNIZ et al., 2002) thus suggesting changes in the trophic state and productivity of this environment. According to Dell'Anno et al. (2002), higher phaeopigment than chlorophyll-a concentrations can be attributed to high turbidity, chemical contamination or some other factor affecting the photosynthetic potential of primary producers and indicates a huge amount of detritus in primary material (PUSCEDDU et al., 2003). In addition, primary production in the study area is controlled by the saline and turbidity front oscillations from west to east (CALLIARI et al., 2009). Therefore, the predominance of phaeopigments in most of the stations, suggests a high sedimentation of partially degraded organic detritus, due to variations in primary productivity associated with different sources of natural and anthropogenic disturbances.

Carbohydrates are the main organic compounds produced by autotrophic organisms by photosynthesis, being part of the structural and reserve tissues of aquatic and terrestrial plants. Also, microphytobenthos produce large amounts of exocellular carbohydrates mostly derived from metabolic activity in response to variations in light intensity, nutrient availability, salinity and taxonomic composition of the biofilm (WELKER et al., 2002). High temporal variability in carbohydrates may be related to variations in some of these factors. Furthermore, high concentrations of carbohydrates, similar to those recorded in this study, are typical for organic detritus sink systems (PUSCEDDU et al., 2003). Therefore, the carbohydrate content in sediments from Montevideo may originate from several sources such as sedimentation of planktonic microalgae, benthic primary production or riverine input of terrestrial compounds. Protein concentrations in sediments reflect the productivity of the system, as they are indicative of microalgal biomass and mobilize more rapidly than carbohydrates, which are more refractory (DANOVARO et al., 1999). In detritus sink systems, increments in protein content can be related to the complexion of nitrogen during detritus aging, but also to bacterial biomass linked to the accumulation and degradation of this organic material on the bottom (FABIANO; DANOVARO, 1994). High protein content related to high bacterial densities have been reported in eutrophic and sediments (VEZZULLI and FABIANO, 2006). In addition, in shallow marine environments with a close couple between pelagic and protein content recorded benthic compartments, microalgae blooms can play an important role by exporting petrogenic hydrocarbons to the bottom (DACHS et al., 1997). In this sense, the recently produced organic particles derived from phytoplankton blooms can act as favorable adsorption matrices of PAH (WANG et al., 2001) by carrying them to the bottom during sedimentation processes. Thus, the high protein content in Montevideo Bay appears to indicate the presence of recently produced organic matter, but also a high amount of partially degraded organic material derived from both primary production and anthropogenic sources. The mean annual values of photosynthetic pigments, carbohydrates and proteins showed the same geographical trend. However, temporal variations in these factors did not always display the same pattern. Probably, seasonal variations of these factors are related to natural fluctuations in the productivity of this system, whereas the geographical trend is associated to the organic pollution gradient. Significant protein enrichment is typical of hypertrophic and impacted areas, with a progressive decrease in proteins and an increase in carbohydrates to meso-oligotrophic environments (VEZZULLI; FABIANO, 2006).

The protein-hypertrophic state of the Montevideo Bay is supported by both water column nutrient and chlorophyll-a concentration. In this sense, Centurión et al. (2007), Danulat et al. (2002) and Nagy et al. (1987) also defined the internal bay as hypertrophic because of the extremely high water

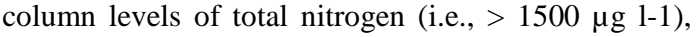
total phosphorus (> $60 \mu \mathrm{g} 1-1$ ), and chlorophyll biomass (> $60 \mu \mathrm{g} \mathrm{1-1)}$. In addition, they also reported that nitrogen levels were 4-fold higher than those of the adjacent coastal zone and the Río de la Plata, and phosphorus values were 1.5-3-fold higher.

In the present study, protein content declined from Montevideo Bay to the adjacent coastal zone, thus indicating a gradient in trophic conditions. Carbohydrate and protein levels in the Montevideo coastal zone are similar to those reported for other highly disturbed areas. For example, in Italy, in a harbor area of the Southern Adriatic Sea, maximum protein and carbohydrate concentrations of $13.99 \mathrm{mg}$ g-1 and $11.99 \mathrm{mg}$ g-1 respectively, were observed (DELL'ANNO et al., 2002). The values reported here are in the same range as those of the north-western Mediterranean coastal zone (ROSSI et al., 2003) and upwelling areas of Chile (NEIRA et al., 2001). We have observed higher protein and lower carbohydrate content than those observed by Pusceddu et al. (2003) in transitional ecosystems of the west coast of Sicily. 
Nevertheless, we did not obtain the same trophic classification for all the stations using the threshold values for carbohydrates and proteins set by Dell'Anno et al. (2002). In fact, based on protein content most stations were classified as hypertrophic, while according to carbohydrate levels, most of them can be considered meso-oligotrophic and some eutrophic. Eutrophic systems are characterized by high nitrogen accumulation rates and higher protein than carbohydrate concentrations (VEZZULLI; FABIANO, 2006), as observed in this study. In contrast, in non-disturbed detritus sink systems, dominance of carbohydrates over proteins is often registered (PUSCEDDU et al., 1997). In addition, contrasting trophic conditions between the pelagic and the benthic environments have also been observed elsewhere (PUSCEDDU et al., 2003). However, this is not the case of the present work as the Montevideo coastal zone is influenced by the Río de la Plata estuary, which is moderately eutrophic with high nitrogen levels (NAGY et al., 2002). Therefore, the more conservative nature of carbohydrates than of proteins, together with a high availability of nitrogen, may be responsible for the lesser sensitivity of carbohydrates as descriptors of the trophic state of this particular system.

The identified diatom species mirror the myxohaline conditions in the study area (Fig. 3 through 6). The most abundant species correspond to the Aulacoseira group, which includes cosmopolitan species often observed in meso to eutrophic freshwater conditions (KRAMMER ; LANGE-BERTALOT, 1991; VAN DAM et al., 1994). This group of species is very abundant in both Paraná and Uruguay Rivers but also in the Río de la Plata itself (O'FARRELL et al., 2001; METZELTIN et al., 2005). Thus, the inputs from these rivers into Río de la Plata carry allochthonous specimens in addition to the autochthonous ones. The Pantanoso and Miguelete Streams (Fig. 1), being eutrophic (IMM, 2005), probably represent a further input of Aulacoseira spp. into the bay and the adjacent coastal zone; however, studies on the diatom composition in the study area are lacking. The second most abundant species were Actinocyclus curvatulus and Actinocyclus gallicus. Actinocyclus curvatulus is a planktonic neritic species often observed in nutrient-rich marine waters (ONODERA; TAKAHASHI, 2008) and which has been widely recorded in the Río de la Plata (FRENGUELLI, 1941; MÜLLER-MELCHERS, 1953). In our case it was equally observed in Montevideo Bay and the adjacent coastal zone. Actinocyclus gallicus is a coastal sublittoral species which has been recorded in New Caledonia and the Caribbean (WITKOWSKI et al., 2000). Other less abundant species, i.e., Coscinodiscus excentricus, Coscinodiscus radiatus, Hyalodiscus subtilis, Paralia sulcata, Actinocyclus normanii, Amphora copulata, Cyclotella meneghiniana, Nitzschia linearis, Pleurosira leavis, Pleurosira minor, Staurosira pinnata and Ulnaria ulna, have already been observed in coastal environments and lakes of Uruguay (METZELTIN; GARCÍA-RODRÍGUEZ, 2003; GARCÍA-RODRÍGUEZ et al., 2004a, b), and their environmental preferences are shown in Figs. 3 through 5. The co-occurrence of freshwater and marine/brackish taxa implies myxohaline conditions in the study area, and since similar diatom composition has been already observed in the coastal lagoons of SE Uruguay (both fossil and present samples, GARCÍA-RODRÍGUEZ et al., 2004a, b), the local environmental preferences are well known.

The diatom data suggest that there is either seasonal variability or a high degree of patchiness in floristic composition as cluster analyses identified different station-groups for different seasons (LONGPHUIRT et al., 2007). We only observed significant species turnover between station $\mathrm{E}$ and station $\mathrm{N}, \mathrm{O}$ and $\mathrm{K}$. Winter was the season that showed the best differentiation between Montevideo Bay and the adjacent coastal zone. The high percentages of the Aulacoseira group are probably related to the increased winter rainfall, with a concomitant increase in the discharge flow from both the Paraná and Uruguay Rivers and Pantanoso and Miguelete streams. Therefore, low percentages of marine/brackish diatoms were recorded in the adjacent coastal zone during this season. However, high values of Dichtyocha fibula at stations $\mathrm{M}$ and $\mathrm{K}$ could be explained because both salinity and temperature values (see Table $1 \mathrm{~B}$, stations $\mathrm{MW}$ and $\mathrm{KW}$ ) were close to the species optima (i.e., salinity $=24$, temperature $=10$ ${ }^{\circ} \mathrm{C}$, VALKENBURG; NORRIS, 1970). This is related to the bottom saline front, which according to our data (Table 1B) was positioned at stations $\mathrm{M}$ and $\mathrm{K}$.

Cluster analysis of spring samples (Fig. 4), showed no clear differentiation between the internal bay and the adjacent coastal zone, as the diatom assemblages displayed similar composition. Summer was similar to spring in the sense that no clear differentiation between the internal bay and the adjacent coastal zone was detected. The upper arm of the cluster diagram consisted of two internal stations and two stations of the adjacent coastal zone (i.e., N, $\mathrm{O}, \mathrm{B}, \mathrm{C})$, which were co-dominated by freshwater and marine/brackish species. Similarly, the lower arm of the cluster diagram (i.e., station D through station K) also consisted of stations from the internal bay and the adjacent coastal zone and co-dominance of freshwater and marine/brackish species was observed as well. This highlights the myxohaline nature of the study area. Furthermore, most of the stations corresponding to the summer sampling were grouped in the top-left quadrant of the ordination diagram, thus showing a 
positive correlation to salinity (Fig. 7). Therefore the highest salinity values were achieved during summer, probably because of the low rainfall and high evaporation rates commonly observed in that season (CONDE; SOMMARUGA, 1999).

In autumn, station E showed a very different diatom composition from that of the other stations, as the Aulacoseira group showed extremely low abundance values. Instead, Amphora copulata and Biddulphia sp. accounted together for almost $60 \%$ of the relative abundances. Such a diatom assemblage was only observed in this season at this station. The rest of the cluster diagram grouped stations of the internal bay and the adjacent coastal zone, and exhibited diatom assemblages similar to those already described for the other seasons (i.e., mostly codominated by Aulacoseira group and Actinocyclus curvatulus and Actinocyclus gallicus).

The above discussed station-groups derived from the diatom composition clearly indicate that the diatom distribution is uneven, with a high degree of diatom patchiness in the surface sediments (LONGPHUIRT et al., 2007). However, it can be recognized that the freshwater diatoms are the dominant taxa, but most of the co-dominant species come from marine/brackish environments. Thus, the diatom composition reliably mirrors the mixing of salinity conditions throughout the year, as observed in several small estuarine systems of the southern coast of Uruguay (METZELTIN; GARCÍA-RODRÍGUEZ, 2003). However, since axis 1 of the ordination diagram explained $\sim 66 \%$ of variance in speciesenvironment relationship, organic matter composition and trophic conditions appear to be hierarchically more important than salinity in controlling the diatom distribution. In this sense, protein levels indicate that internal bay stations are mostly eutrophic to hypertrophic. This is due to the combined action of all human impacts (i.e., petrol refinery, leather/food industry facilities, navigation, harbor activities) and the lack of sanitation in a fairly large portion of the city, where most industry facilities and povertystricken populations are located. On the other hand, the adjacent coastal zone appears to represent a mesooligotrophic to eutrophic environment because the contamination levels become more diluted the further removed they are from the Bay and the waste water is discharged through a sewage pipe. In addition, this trophic state is a consequence of the baseline trophic state of the Río de la Plata which is moderately eutrophic (NAGY et al., 2002). However, increasing trends in both freshwater and nutrient loads, and the low potential to dilute and flush nutrients, suggest eutrophication is likely to intensify in the Rio de la Plata (NAGY et al., 2002).

When the diatom composition and environmental data from all the stations/seasons were analyzed together by canonical correspondence analysis, a multivariate relationship between diatoms and the organic contamination gradient was detected. Internal bay stations were positively correlated to organic matter, protein and carbohydrate content. In this sense, some of the diatom species of this section of the diagram could be related to such environmental degradation (PRYGIEL; COSTE, 2000). In particular, Actinocyclus normanii and Cyclotella meneghiniana are well known cosmopolitan proxies for aquatic degradation, eutrophication and contamination (PRYGIEL; COSTE, 2000; GARCÍA-RODRÍGUEZ et al., 2007b). Such degradation and hypertrophy of the inner Montevideo Bay have already been documented (DANULAT et al., 2002; VENTURINI et al., 2004; MUNIZ at al., 2002, 2004a, b; BURONE et al., 2006). Particularly, Burone et al. (2006) analyzed the benthic foraminiferal assemblages and observed that, in Montevideo Bay, there was an extremely poor foraminiferal fauna - including a totally azoic station - thus evidencing the high degree of local contamination. The adjacent coastal zone, with moderate pollution levels, exhibited a higher number of foraminiferal species than that of the internal bay, where dominance of Ammonia tepida was recorded. In addition to this, Burone et al. (2006) detected high percentages of abnormal tests in Montevideo Bay, which were ultimately related to the high contamination level of multiple sources. In the case of the diatoms, we also observed a difference in diatom composition between the bay and the coastal zone, but no abnormal diatom valves were recorded. The stations of the adjacent coastal zone in this study (i.e., $\mathrm{G}$ through $\mathrm{R}$ ) were positively related to salinity. In this sense, both Paralia sulcata and Dichtyocha fibula are both typical species of marine brackish conditions, but the co-occurrence of freshwater species such as those of the Aulacoseira group and Eunotia sp., suggests mixed estuarine conditions. The diatom assemblages of the internal bay also indicate mixed salinity conditions, as freshwater species (Actinocyclus normanii, Cyclotella meneghiniana, Amphora copulata) together with marine brackish species (Coscinodiscus radiates, Coscinodiscus excentricus, Actinocyclus curvatulus, Actinocyclus gallicus, Hyalodiscus subtilis), were recorded.

The diatom data in relation to the trophic and salinity gradients presented here fit well with previous trophic state assessments (DANULAT et al., 2002; MUNIZ at al., 2002, 2004a, b; VENTURINI et al., 2004; BURONE et al., 2006) but also with the findings proposed by Dell' Anno et al. (2002), at least in terms of protein content. Even though previous research in the study area has clearly demonstrated the effects of human impacts on both benthic macrofauna and foraminiferal assemblages, heavy metal contamination and hydrocarbons were utilized as 
variables (DANULAT et al., 2002; MUNIZ at al., 2002, 2004a, b; VENTURINI et al., 2004; BURONE et al., 2006). In the present assessment, we introduce diatom species combined with the biochemical composition of organic matter to assess environmental degradation in the Montevideo coastal zone. Thus, the present data imply an improvement in our ability to assess organic contamination in the study area, since both biological and biopolymer variables are introduced as tools for assessing the benthic health/degradation of one of the most densely populated regions of the Río de la Plata.

\section{ACKNOWLEDGEMENTS}

This paper was funded by the "Programa de Desarrollo Tecnológico" (Project PDT 6328), and the Municipality of Montevideo (Project BID-IMM). PEDECIBA, SNI-ANII and CSIC-Program "Contratación de investigadores provenientes del exterior" are also thanked for their financial support.

\section{REFERENCES}

ACHA, M. A.; MIANZAN, H.; GUERRERO, R.; CARRETO, J.; GIBERTO, D.; MONTOYA, N.; CARIGNAN, M. An overview of physical and ecological processes in the Rio de la Plata Estuary. Continent. Shelf Res., v. 28, p.579- 588.

AYUP, R. N. Comportamento dos sedimentos em suspensão no Río de la Plata exterior e proximidades. Pesquisas, v.18, p.39-68, 1986.

BIGOT, L.; CONAND, C.; AMOUROUX, J. P.; FROUIN, P.; BRUGGEMANN, H.; A. GRÉMARE, A. Effects of industrial outfalls on tropical macrobenthic sediment communities in Reunion Island (Southwest Indian Ocean). Mar. Pollut. Bull., v.52, p.865-880, 2006.

BOON, A. R.; DUINEVELD, G. C. A.; BERGHUIS, E. M.; VAN DER WEELE, J. A. Relationships between benthic activity and the annual phytopigment cycle in near-bottom water and sediments in the southern North Sea. Estuar. coast. Shelf Sci., v. 46, p.1-13. 1998.

BRUGNOLI, E.; MUNIZ, P.; VENTURINI, N.; BURONE, L. Environmental Perturbation and Coastal Benthic Biodiversity in Uruguay. 2007. In: WILLIS, I.C. (Ed.). Progress in environmental research. New York: Nova Publisher, 2007. Chapter 2, p. 75-126.

CALLIARI, C.; BRUGNOLI, E.; FERRARI, G.; VIZZIANO, D. Phytoplankton distribution and production along a wide environmental gradient in the South-West Atlantic off Uruguay. Hydrobiologia, v.620, p. 47-61. 2009

CARP-CTMFM. Protección ambiental del Rio de la Plata y Frente Marítimo. Electronic document. <http://www.freplata.org/documentos/archivos/Documen tos_Freplata/Documento_de_proyecto_web.pdf1999.>

CENTURIÓN V.; KANDRATAVICIUS, N.; SILVA DE PABLO, M. ¿Habrá variado la calidad ambiental de la bahía de Montevideo y su zona costera adyacente en 10 años? Montevideo: Facultad de Ciencias, UdelaR, 2007. Technical Report, Sección Oceanología, p. 35. (in Spanish).

CLOERN, J. E. Our evolving conceptual model of the coastal eutrophication problem. Mar. Ecol. Prog. Ser., v.210, p. 223-253. 2001.

CONDE, D.; SOMMARUGA, R. A review of the state of Limnology in Uruguay. In: WETZEL R.G.; GOPAL, B. (Ed.). Limnology in developing countries. vol 2. New Delhi: International Association for Limnology (SIL), 1999. p. 1-31.

DACHS, J.; BAYONA, J. M.; RAOUX, C.; ALBAIGÉS, J. Spatial distribution, vertical profiles and budget of polycyclic aromatic hydrocarbons in western Mediterranean. Environ. Sci. Tech., v. 31, p. 682-688. 1997.

DANULAT, E.; MUNIZ, P.; GARCÍA-ALONSO, J.; YANNICELLI, B. First assessment of the highly contaminated harbour of Montevideo, Uruguay. Mar. Pollut. Bull., v. 44, p. 554-565. 2002

DANOVARO, R. D.; MARRALE; DELLA CROCE, N. ; PARODI, P.; FABIANO, M. Biochemical composition of sedimentary organic matter and bacterial distribution in the Aegean Sea trophic state and pelagic-benthic coupling. J. Sea Res., v. 42, p.117-129. 1999.

DELL'ANNO, A.; MEI, M. L.; PUSCEDDU, A.; DANOVARO, R. Assessing the trophic state and eutrophication of coastal marine systems: a new approach based on the biochemical composition of sediment organic matter. Mar. Pollut. Bull., v. 44, p.611-622. 2002.

DESA, E.; ZINGDE, M. D.; VETHAMONY, P. ; BABU, M. T.; . D'SOUSA, S. N.; X. N, VERLECAR, X. N. Dissolved oxygen--a target indicator in determining use of the Gulf of Kachchh waters. Mar. Pollut. Bull., v. 50, p.73-79. 2005.

DUBOIS, M.; K. GILLES; J. K. HAMILTON, P. A. REBERS; F. Smith. Colorimetric method for determination of sugars and related substances. Analyt. Chem., v. 28, p.350-356. 1956.

FABIANO, M.; DANOVARO, R. Composition of organic matter in sediments facing a river estuary (Tyrrhenian Sea): relationships with bacteria and microphytobenthic biomass. Hydrobiologia, v. 277, p. 71-84. 1994

FOLK, R. L.; WARD, W. C. Brazos River bar: a study of the significance of grain size parameters. J. sedim. Petrology, v. 27, p. 3-26. 1957.

FRENGUELLI, J. Diatomeas del Río de la Plata. Revta Museo Nac. La Plata. Tomo III, p.213-334, 1941.

FRENGUELLI, J. Las diatomeas del Platense. Revta Mus. Nac. La Plata. Tomo III, p. 77-221, 1945.

FREPLATA. Análisis diagnóstico transfronterizo del Río de la Plata y su Frente Marítimo. Proyecto Protección Ambiental del Río de la Plata y su Frente Marítimo. Proyecto PNUD/GEF/RLA/99/G31, 2004. Documento Técnico, p. 313.

GARCÍA-RODRÍGUEZ, $\quad$ F.; $\quad$ METZELTIN, $\quad$ D.; SPRECHMANN, P.; TRETTIN, R.; STAMS, G; BELTRÁN-MORALES, L. F. Upper Pleistocene and Holocene paleosalinity and trophic state changes in relation to sea level variation in Rocha Lagoon, southern Uruguay. J. Paleolimnol., v. 32, p. 117-135, 2004a. 
GARCÍA-RODRÍGUEZ, F.; SPRECHMANN, P.; METZELTIN, D.; SCAFATI, D. L. ; MELENDI, D. L.; VOLKHEIMER, W.; MAZZEO, N. ; HILLER, A. ; VON TÜMPLING JR, W. ; SCASSO, F. Holocene trophic state changes in relation to sea level variation in Lake Blanca, SE Uruguay. J. Paleolimnol., v.31, p. 99$115,2004 \mathrm{~b}$

GARCÍA-RODRÍGUEZ, F.; BATE, G. C.; SMAILES; J. B.; ADAMS D.; METZELTIN, D. Multivariate analysis of dominant and sub-dominant epipelic diatoms and water quality data from South African rivers. Water SA, v.33, p.653-658, 2007a.

GARCÍA-RODRÍGUEZ F.; ANDERSON, C. R.; ADAMS, J. B. Paleolimnological assessment of human impacts on an urban South African lake. J. Paleolimnol., v.38, p. 297-308, 2007b.

GERCHACOV, S. M; HATCHER, P.G. Improved technique for analysis of carbohydrates in the sediment. Limnol. Oceanogr., v.17, p. 938-943. 1972.

GÓMEZ-ERACHE, M.; VIZZIANO, D.; MUNIZ, P.; NAGY, G. J. The Health of the Rio de la Plata system: Northern Coast, Uruguay:17-35. In: CHOPIN, T.; WELLS, P. G. (Ed.). Opportunity and Challenges for Protecting, Restoring and Enhancing Coastal Habitats in the Bay of Fundy. THE BAY OF FUNDY SCIENCE WORKSHOP, Saint John, New Brunswick, September 19-21, 2000. Proceedings... Case Study/Workshop: Nutrification of Coastal Waters. BoFEP Programme, New Brunswick, Saint John, Canada, September, 2000. Environment Canada, Atlantic Region Occasional Report No 17, Environment Canada, Dartmouth, Nova Scotia. 2001, p.237.

HAMMER, Ø.; HARPER, D. A. T.; RYAN, P. D. PAST Palaeontological Statistics, ver. $1.81 . \quad 88$ pp.< http://folk.uio.no/ohammer/past 2008>.

HARTREE, E. F. Determination of proteins: a modification of the Lowry method that gives(?) a linear photometric response. Analyt. Chem., v. 48: p. 422-427. 1972.

HEIRI, O.; LOTTER, A. F.; LEMCKE, G. Loss on ignition as a method for estimating organic and carbonate content: reproducibility and comparability of the results. J. Paleolimnol., v. 25, p. 101-110. 2001

IMM. Programa de cuencas menores de Montevideo. Informe 2005. <http://www.montevideo.gub.uy/ ambiente/documentos/cuencasmenores.pdf . 2005.>.

KARST, T. L.; SMOL, J. P . Paleolimnological evidence of limnetic nutrient concentration equilibrium in a shallow, macrophyte-dominated lake. Aquat. Sci. v. 62, p. 2038. 2000.

KELLY, M. G. Use of the trophic diatom index to monitor eutrophication in rivers. Wat. Res., v. 32, p. 236-242. 1998

KRAMMER, K.; LANGE-BERTALOT, H. Bacillariophyceae. 3. Teil: Centrales, Fragilariaceae, Eunotiaceae. In: ETTL, H.; GERLOFF, J.; HEYNIG, H.; MOLLENHAUER, D. (Ed.). Süsswasserflora von Mitteleuropa. Band 2/3. Stuttgart: Gustav Fischer Verlag, 1991. p. 598.

LONGPHUIRT, S. N.; CLAVIER, J.; GRALL, J.; CHAUVAUD, L.; LE LOC'H, F.; LE BERRE, I.; FLYE-SAINTE-MARIE, J.; RICHARD J.; LEYNAERT, A. Primary production and spatial distribution of subtidal microphytobenthos in a temperate coastal system, the Bay of Brest, France. Estuar. coast. Shelf Sci., v. 74, p. 367-380. 2007.

LÓPEZ-LABORDE, J. Marco geomorfológico y geológico del Río de la Plata. In: WELLS, P.G.; DABORN, G.R. (Ed.). The Río de la Plata: An environmental Overview. An EcoPlata project Background Report. Dalhousie University, Halifax, Nova Scotia, Canada, 1997. p.256

LORENZEN, C. J. Determination of chlorophyll and pheopigments: spectrophotometric equations. Limnol. Oceanogr., v. 12, p. 343-346, 1967

LOWRY, O. H.; ROSEBROUGH, N. J.; FARR, A. L.; RANDALL, R. J. Protein measurement with the folin phenol reagent. J. biol. Chem., v. 19, p. 265-275. 1951.

METZELTIN， D;: GARCÍA-RODRÍGUEZ，F， Las Diatomeas Uruguayas. Montevideo: DIRAC Ediciones, Facultad de Ciencias, 2003. p. 208.

METZELTIN, D.; LANGE-BERTALOT, H.; GARCÍARODRÍGUEZ, F. Diatoms of Uruguay - taxonomy, biogeography, diversity. In: LANGE-BERTALOT, $\mathrm{H}$. (Ed.). Iconographia Diatomologica. v. 15. Germany: A. R. G. Gantner Verlag, distributed by Koeltz Scientific Books. Koenigstein, 2005. p.737.

MORESCO, H.; DOL, I. Metales en sedimentos de la Bahía de Montevideo. Rev. Asoc. Ciencias Nat. del Litoral, v. 27, p. 1-5. 1996.

MOYANO, M.; MORESCO, H.; BLANCO, J.; ROSADILlA, M.; A. CABALlERO, A. Baseline studies of coastal pollution by heavy metals, oil and PAHs in Montevideo. Mar. Pollut. Bull., v. 26, p.461464, 1993.

MÜLLER-MELCHERS, F. C. Sobre algunas diatomeas planctónicas de Atlántida (Uruguay). Physis, v. 20, n. 59, p. 459-466. 1953.

MUNIZ, P.; VENTURINI, N.; MARTÍNEZ, A. Physicochemical and pollutants of the benthic environment of the Montevideo Coastal Zone, Uruguay. Mar. Pollut. Bull., v. 44, p. 962-968, 2002.

MUNIZ, P.; VENTURINI, N.; GOMEZ-ERACHE, M. Spatial distribution of chromium and lead in sediments from coastal areas of the Río de la Plata estuary (Montevideo, Uruguay). Braz. J. Biol., v. 64, p. 103116. 2004a.

MUNIZ, P.; DANULAT, E.; YANNICELLI, B.; GARCÍAALONSO, J.; MEDINA, G.; BÍCEGO, M. Assessment of contamination by hydrocarbons and heavy metals in sediments of Montevideo Harbour (Uruguay). Environ. Int., v. 29, p. 1019-1028, 2004b.

NAGY, G. J.; GÓMEZ-ERACHE, M.; LÓPEZ, C. H.; PERDOMO, A. Distribution patterns of nutrients and symptoms of eutrophication in the Rio de la Plata River Estuary System. Hydrobiologia, v. 475. p. 125-139. 2002.

NAGY, G. J.; MARTIÍNEZ, C. M.; CAFFERA, R. M. ; PEDROSA, G.; FORBES, E. A.; PERDOMO; A. C.; LÓPEZ-LABORDE, J. Hydroclimatic setting of the Río de la Plata: An environmental Overview. An EcoPlata project Background Report. Dalhousie University, Halifax, Nova Scotia, Canada, 1997, p. 256.

NAGY, G. J.; PERDOMO, A. C.; RISO, A. D. Algunos aspectos hidroquímicos de la Bahía de Montevideo. Investnes oceanol.Chil., v. 1, n. 1, p. 5-17, 1987. 
NEIRA, C.; SELLANES, J.; SOTO, A.; GUTIÉRREZ, D.; GALLARDO, V. Meiofauna and sedimentary organic matter off Central Chile: response to changes caused by the 1997-1998 El Niño. Oceanologica Acta, v. 24:, p 313-328, 2001.

O'FARRELL, I.; TELL, G.; PODLEJSKI, A. Morphological variability of Aulacoseira granulata (Ehr.) Simonsen (Bacillariophyceae) in the Lower Paraná River (Argentina). Limnology, v. 2, p. 65-71, 2001.

ONODERA, J.; TAKAHASHI, K. Long-term diatom fluxes in response to oceanographic conditions at Stations $\mathrm{AB}$ and SA in the central subarctic Pacific and the Bering Sea, 1990-1998. Deep. Sea Res. I <doi:10.1016/j.dsr.2008.08.006. 2008>.

PRYGIEL, J.; COSTE, M. Guide méthodologique pour la mise en ouvre de l'Indice Biologique Diatomées. NF T 90-354 . Bordeaux: Agences de l'Eau-Cemagref, 2000. $134 \mathrm{p}$.

PUSCEDDU, A.; DELL'ANNO, A.; DANOVARO, R.; MANINIE, E. G; SARA, A.; FABIANO, M. Enzymatically hydrolyzable protein and carbohydrate sedimentary pools as indicators of the trophic state of detritus sink systems: a case study in a Mediterranean coastal lagoon. Estuaries, v. 26, p.641-650, 2003.

PUSCEDDU, A.; SARA, A.; MAZZOLA, M.; FABIANO, M. Relationships between suspended and sediment organic matter in a semi-enclosed marine system: The Stagnone di Marsala sound (Western Sicily). Wat. Air Soil Pollut., v. 99, p. 343-352, 1997.

RICE, D. L. The detritus nitrogen problem, new observations and perspectives from organic geochemistry. Mar. Ecol. Prog. Ser., v. 9, p. 153-162, 1982.

ROSSI, S.; GRÉMARE, A.J-M.; GILI, J. M.; AMOUROUX, E.; JORDANA, G.; VÉTION, G. Biochemical characteristics of settling particulate organic matter at two north-western Mediterranean sites: a seasonal comparison. Estuar. coast. Shelf Sci., v. 58, p. 423-434, 2003.

SUGUIO, K. Introdução à sedimentologia. São Paulo: Edgard Blucher, 1973. $317 \mathrm{p}$.

TER BRAAK, C. F. J.; SMILAUER, P. CANOCO Reference Manual and User's Guide to CANOCO for Windows: Software for Canonical Community Ordination (version 4). Microcomputer Power (Ithaca, NY, USA). 1998, $352 \mathrm{p}$.

VALKENBURG, S. D; NORRIS, R. E. The growth and morphology of the sillicofragellate Dichtyocha fibula Ehrenberg in culture. J. Phycol., v. 6, p. 48-54, 1970.

VAN DAM, H.; MERTENS, A.; SINKELDAM, J. A coded checklist and ecological values of freshwater diatoms from the Netherlands. Neth. J. aquat. Ecol., v. 28, p. 117-133, 1994.
VENTURINI, N.; MUNIZ, P.; RODRÍGUEZ, M. Macrobenthic subtidal communities in relation to sediment pollution: the phylum-level meta-analysis approach in a south-eastern coastal region of South America. Mar. Biol., v. 144, p. 119-126, 2004.

VEZZULLI, L.; FABIANO, M. Sediment biochemical and microbial variables for the evaluation of trophic status along the Italian and Albanian continental shelves. J. mar. Biol. Assoc. UK, v. 86, p 27-37, 2006.

VOLLENWEIDER, R. A.; GIOVANARDI, F.; MONTANARI, G.; RINALDI, F. Characterisation of the trophic conditions of marine coastal waters with special reference to the NW Adriatic Sea: Proposal for a trophic scale, turbidity and generalised water quality index. Environmetrics, v. 9, p. 329-357, 1998.

WANG, X. C.: ZHANG, Y. X.; CHEN, R. F. Distribution and partitioning of polycyclic aromatic hydrocarbons (PAHs) in different size fractions in sediments from Boston Harbor, United States. Mar. Pollut. Bull., v.11, p.1139-1149, 2001

WELKER C. E. SDRIGOTTI; S. COVELLI; J. FAGANELI. Microphytobenthos in the Gulf of Trieste (Northern Adriatic Sea): Relationships with Labile Sedimentary Organic Matter and Nutrients. Estuar. coast. Shelf Sci., v.55, p. 259-273, 2002

WEISS, R. The solubility of nitrogen, oxygen, and argon in water and seawater. Deep Sea Res., . v.17, p. 721-35, 1970.

WILSON, S. E.; CUMMING, B.; SMOL, J. P. Diatomsalinity relationships in 111 lakes from the interior plateau of British Columbia, Canada: the development of diatom based model for paleosalinity reconstructions. $\mathbf{J}$. Paleolimnol. v 12, p. 197-221, 1994.

WITKOWSKI, A.; LANGE-BERTALOT, H.; METZELTIN, D. Diatom flora of marine coasts I. In: LANGEBERTALOT (Ed.). Iconographia Diatomologica, v. 7. Königstein: Koeltz Scientific Books, 2000. 925 p.

(Manuscript received 10 February 2010; revised 13 December 2010; accepted 23 May 2011) 